Direct and indirect impacts of shoreline development on shallowwater benthic communities in a depauperate estuarine system

Cassie D. Lovall

Rochelle D. Seitz

Kathleen E. Knick

Follow this and additional works at: https://scholarworks.wm.edu/vimsarticles

Part of the Marine Biology Commons 


\section{Direct and indirect impacts of shoreline development on shallow-water benthic communities in a depauperate estuarine system}

Virginia Institute of Marine Science, College of William \& Mary, P.O. Box 1346, Gloucester Point, Virginia 23062.

* Corresponding author email: <seitz@vims.edu>,telephone: 804-684-7698; fax: 804-6847399.
Date Submitted: 26 May, 2016. Date Accepted: 28 November, 2016. Available Online: 3 January, 2017.

\author{
Cassie D Lovall \\ Rochelle D Seitz* \\ Kathleen E Knick
}

\begin{abstract}
Modification of natural coastlines is prevalent as human coastal populations swell and effects of global climate change become clearer. We investigated effects of shoreline hardening and environmental factors on benthic infauna and trophic structure in the Patuxent River, Maryland, a stressed mesohaline Chesapeake Bay tributary. We characterized differences in density, diversity, biomass, and trophic structure for large $(>3 \mathrm{~mm})$ and small $(>500 \mu \mathrm{m})$ infauna adjacent to natural marsh, riprap, and bulkhead (i.e., seawall) shores throughout the river. Akaike information criterion model comparisons were used to assess the evidence for differences in benthic infaunal structure using primary (shoreline type) and secondary (e.g., sediment grain size, predator abundance) variables. There was strong evidence for secondary factors to explain reduced biomass of infauna adjacent to developed shorelines. For large infauna, evidence suggested that shorelines with riprap had reduced diversity, and with bulkhead had increased diversity. Increased wave energy and chlorophyll- $a$ were associated with high densities for both size fractions riprap shorelines. Trends suggested high biomass and more carnivores, omnivores, and deposit feeders adjacent to natural marshes, compared to low biomass and more filter feeders at developed shorelines. While similar studies in lower Chesapeake Bay systems have shown clear effects of shoreline type on benthic communities, the extensive development in the Patuxent River may contribute to larger-scale stress, yet some shoreline-specific effects were detected. Non-parametric tests revealed differences in infaunal communities by shoreline type and river zone. Thus, the benthic community in this estuary is driven by local shoreline effects, as well as large-scale physical and biotic factors.
\end{abstract}

Human population growth and increases in commercial, residential, and recreational activity near coasts has resulted in alteration of natural shorelines worldwide (Airoldi and Bulleri 2011, Dugan et al. 2011). To deal with increasing development in coastal communities, artificial infrastructure, such as bulkheads (vertical seawalls made of concrete, wood, or metal), revetments (large boulders, or "riprap"), groins, 
jetties, breakwaters, and piers, are often implemented to combat erosion, prevent flooding, and provide access for marine vessels (Dugan et al. 2011).

Artificial structures dominate coastal regions in Europe, the Mediterranean, Japan, Australia, and the US, covering $>50 \%$ of the shoreline in some cases (Dugan et al. 2011, Gittman et al. 2015). On the California coast, shoreline hardening increased by $400 \%$ between the 1970 s and 1990 s, and currently greater than half of the shorelines of some estuaries and bays-including Chesapeake, Barnegat, and San Diego-are armored (Dugan et al. 2011). Although certain hard structures may provide additional habitat to some epibiota (Browne and Chapman 2011, Chapman and Underwood 2011), they also may alter flow dynamics (Miles et al. 1996), sediment properties (Ahn and Choi 1998), and nutrient and food-web characteristics (Rosenberger et al. 2008). Wave scour and reflection from vertical structures can present a severe limitation to less-resilient species and those adapted to gently sloping coasts (Dugan et al. 2011). Overall, the fragmentation or complete replacement of natural, complex habitat results in changes to infauna, epifauna, and fish communities on the Mississippi Gulf Coast (Peterson et al. 2000, Partyka and Peterson 2008), intertidal and supratidal invertebrates in Puget Sound (Sobocinski et al. 2010), and intertidal bivalves in the Yellow Sea (Ahn and Choi 1998).

Along the mid-Atlantic region of North America, bulkhead and riprap often are installed and replace tidal salt marshes, which play an integral role in estuarine function (Valiela 1995, Bertness 2007, Gedan et al. 2009). The organic-rich sediments of marshes tend to support abundant benthic communities, which influence ecological functioning through nutrient transformation and fluxes (Snelgrove and Butman 1994, Karlson et al. 2007) and energy flow to higher trophic levels (Virnstein 1977, Diaz and Schaffner 1990, Hines et al. 1990). Benthic species in these habitats, because of their relatively long life spans, sessile nature, and sensitivity to stressors, are important indicators of ecological integrity (Dauer 1993, Hyland et al. 2005).

Large-scale changes in watershed development and land-use patterns can affect adjacent near-shore benthic communities in Chesapeake Bay (Lerberg et al. 2000, Bilkovic et al. 2006, Bilkovic and Mitchell 2013). In addition, there is a link between natural marshes, benthic infaunal (subtidal) prey, and predator abundance (Partyka and Peterson 2008, Seitz and Lawless 2008, Peterson and Lowe 2009, Long et al. 2011, Gittman et al. 2016). In lower Chesapeake Bay, marshes support greater abundances (Seitz et al. 2006, Morley et al. 2012) and diversity (Bilkovic and Roggero 2008) of nearshore nekton and benthic infauna (Seitz et al. 2006, Seitz and Lawless 2008) than either riprap or bulkhead shorelines. In three lower-bay tributaries with moderate productivity and approximately $45 \%-90 \%$ of the shoreline as marsh, levels of infaunal abundance and diversity were greatest near natural marsh, intermediate and variable near riprap shorelines, lowest near bulkhead, and depended on the percentage of developed shoreline throughout the local watershed (Seitz et al. 2006, Seitz and Lawless 2008). In developed systems, infaunal abundance and diversity adjacent to riprap were low, whereas in less-developed tributaries, infaunal abundance and diversity near riprap were similar to those near natural marsh shorelines (Seitz and Lawless 2008), suggesting that the influences from adjacent habitats are important.

Although some studies have examined effects of watershed land use on hydrological and ecological function in the Patuxent River (Costanza et al. 2002), data are scarce regarding local effects of shoreline development on nearshore community structure 
or infaunal trophic diversity in this or other mesohaline Chesapeake Bay tributaries. The Patuxent River is highly developed and can be characterized as a depauperate estuary. Based on 11 yrs of subtidal benthic data collected by the Chesapeake Bay Program (1996-2006; D Dauer, Old Dominion University, pers comm), it falls among the lowest of all tributaries in the bay in terms of infaunal density and diversity. Moreover, with only 34\% natural marsh shoreline in the lower basin (Berman et al. 2003, 2006), the Patuxent River has more shoreline development than other systems in lower Chesapeake Bay, such as the Elizabeth-Lafayette (48\% natural marsh), the Lynnhaven (75\%), and the York River (83\%). The benthic communities adjacent to natural shorelines in less-developed systems may subsidize the loss of benthos at hardened shorelines (Seitz et al. 2006, Seitz and Lawless 2008) and, in these systems, differences in benthos can be seen among shoreline types.

A 2008 pilot study in the Patuxent River revealed subtle differences in density, diversity, and biomass of benthic infauna and catch per unit effort of fish and crabs near natural vs hardened shorelines amidst considerable variability, and we expanded the pilot work into a broad-scale study in the Patuxent River (45 sites). Our objectives for the present study were to categorize infaunal density, diversity, biomass, and feeding guild structure across natural (Spartina alterniflora Loisel.) and altered (riprap, bulkhead) shorelines. We expected that there would be greater infaunal density, diversity, and biomass, greater trophic diversity, and greater fish and crab abundance at natural marshes, intermediate values at riprap, and lowest values at bulkhead sites, based on marsh characteristics (greater habitat suitability and resource provision), the results of prior studies (Seitz et al. 2006, Seitz and Lawless 2008, Bilkovic and Roggero 2008), and the 2008 pilot work noted above. However, because of the system-wide differences between the Patuxent River and some lowerbay systems (e.g., large percentage of developed coastal habitat and depauperate communities), we expected the overall response of benthic communities to shoreline hardening in the Patuxent River to be less dramatic than that in less-altered estuaries. Because benthic infauna respond to other habitat characteristics, such as sediment grain size, nutrient content (Boesch 1973, Snelgrove et al. 2000), and wave energy (Emerson 1989, Schaffner et al. 2001), our objectives also were to evaluate the effects of these secondary variables on infaunal communities among different shoreline types. We expected high variability in the benthos, as is common in benthic systems (Holland et al. 1987, Ysebaert et al. 2005), and thus chose to use an informationtheoretic approach to determine the most influential variables of those measured in the field or modeled (i.e., wave energy) on community structure. We expected that infaunal density, biomass, and physical parameters would differ by shoreline type [e.g., natural marsh (S. alterniflora), riprap, and bulkhead], along with other environmental factors, based on previous studies (Bilkovic et al. 2006, Seitz et al. 2006, Seitz and Lawless 2008). We also expected that shoreline type, sediment type, and predator abundance would be most influential on benthos based on previous studies indicating the importance of those factors (Seitz et al. 2006, Dauer et al. 2000, and Thrush 1999, respectively). We also aimed to examine differences in community structure patterns by river zone, as a gradient in salinity and other physical factors exists with distance from the river mouth. We hypothesized that finer sediment and increased organic content would increase faunal abundance and diversity, as in other benthic studies (Pearson and Rosenberg 1978). Our work in a mesohaline tributary adds to a body of work in the polyhaline lower reaches of Chesapeake Bay to aid 
in understanding the impacts of shoreline development on communities bay-wide, and may provide insight to guide more effective estuarine restoration in developed systems worldwide.

\section{MethodS}

\section{Study Sites}

The present study took place in the Patuxent River, Maryland, a subestuary of Chesapeake Bay, that is approximately $177 \mathrm{~km}$ long and drains approximately 2352 $\mathrm{km}^{2}$ (Dail et al. 1998). Based on a power analysis (infaunal density vs SE) from pilot work conducted in June 2008, 15 replicate sites of each shoreline type (45 sampling sites total) were deemed sufficient to detect differences among shoreline types (Bradley 2011). To ensure a stratified random sampling design, distribute shoreline types evenly throughout the river, and examine some broad-scale effects, the lower basin-mesohaline portion-of the river was divided into three (approximately 11 $\mathrm{km}$ long) river zones (up, mid, down) based on distance from the river mouth. In each river zone, 15 sampling sites (generally 5 per shoreline type, except the downriver zone had 6 bulkhead and 4 riprap sites, and the mid-river zone had 6 riprap and 4 bulkhead sites) were randomly selected (Fig. 1). Data on Patuxent River shoreline types were obtained from the Center for Coastal Resources Management (CCRM; Berman et al. 2003, 2006) from maps (and thus shorelines) that were 3 yrs old, and sites were selected based on the following three criteria: (1) $\geq 80 \mathrm{~m}$ of a given shoreline type, (2) salinity of $\geq 5$, and (3) water depth $\leq 1.2$ m mean low water (MLW). Sites with more than one shoreline type (e.g., bulkhead with salt marsh in front) were excluded, and criterion (1) above aided in the avoidance of confounding structures. While the age of an artificial shoreline may impact the successional stage of the local benthos, a 6-mo "seasoning period" is sufficient to see the development of a representative Chesapeake Bay benthic community (Burke 2010).

All macrofauna and other associated samples (see below) were taken $5 \mathrm{~m}$ from the shoreline at each site. Infauna, water quality, and sediment sampling took place 23-26 June, 2009. Predator sampling, which occurred at an offshore distance as near as possible to $5 \mathrm{~m}$ (depending on water depth; see below), took place 13-16 July, 2009. We noted the tidal stage at which each sample was taken and made sure to sample some of each habitat type on each tidal stage.

\section{Field SAMPLING}

Water Quality and Sediment.-A calibrated YSI Pro-Plus Multi-Parameter Water Quality meter was used at each site to determine water temperature $\left({ }^{\circ} \mathrm{C}\right)$, salinity, and dissolved oxygen (DO, $\mathrm{mg} \mathrm{L}^{-1}$ ). Two sediment samples were taken to 5 - $\mathrm{cm}$ depth for the analysis of grain size, total organic carbon (TOC), and total nitrogen (TN) content. Grain-size was analyzed using a standard wet sieving and pipetting technique (Plumb 1981). Samples were run through an Exeter CE440 elemental analyzer to quantify carbon, hydrogen, and nitrogen $(\mathrm{CHN})$ content. Also, a syringe core of sediment was taken to analyze surface $(0-3 \mathrm{~mm})$ chlorophyll- $a$ (chl- $a$ ) and phaeophytin, using standard methods (Lorenzen 1967, Pinckney and Zingmark 1993), modified by a sonification step and the use of $90 \%$ acetone as an extractant [I Anderson, Virginia Institute of Marine Science (VIMS), pers comm]. Final processing was conducted with a Beckman-Coulter DU 800 spectrophotometer. 


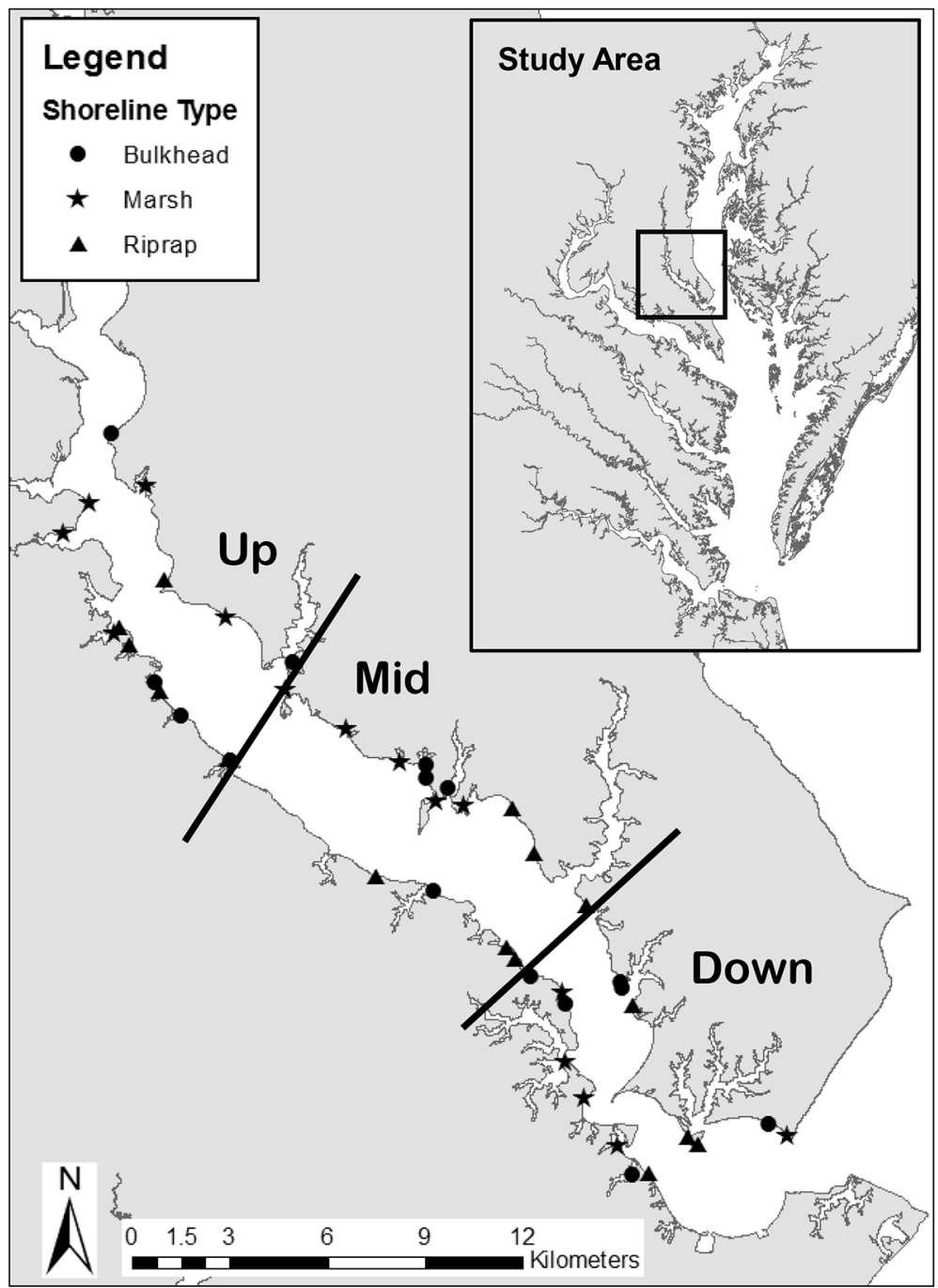

Figure 1. Location of river zones and distribution of sampling sites within each zone of the Patuxent River, MD ( $n=15$ per zone; total $N=45)$. An upper end-point of the sampling area (Upriver) occurred at: $38^{\circ} 30^{\prime} 40.9^{\prime \prime} \mathrm{N}, 76^{\circ} 39^{\prime} 49.3^{\prime \prime} \mathrm{W}$. A lower end-point of the sampling area (Downriver) occurred at: $38^{\circ} 19^{\prime} 10.4^{\prime \prime} \mathrm{N}, 76^{\circ} 25^{\prime} 20.6^{\prime \prime} \mathrm{W}$. Marker shape indicates shoreline type at that site (circle $=$ bulkhead, star $=$ natural marsh, triangle $=$ riprap).

Wave Energy.-Wave energy was estimated using the Wave Exposure Model (WEMo) 4.0. WEMo uses a numerical, one-dimensional model based on linear wave theory to calculate wave propagation in shallow coastal waters, accounting for the combined effects of wind-wave generation, shoaling, and dissipation (Malhotra and Fonseca 2007). Outputs of incorporated bathymetry (estimated from the NOAA National Geophysical Data Center Coastal Relief Model), wind speed/direction (estimated over the sampling dates from the NOAA National Buoy Data Center), shoreline coverage, and point data (i.e., coordinates of the 45 sampling sites) were analyzed to calculate an index of representative wave energy (RWE), representing total wave 
energy $\left(\mathrm{J} \mathrm{m}^{-1}\right)$ in one wave length per unit wave crest width (USCOE 1977, Malhotra and Fonseca 2007) at each site.

Infauna.-We collected two different size fractions of infauna to assess differences among deep-dwelling, sparsely distributed macrofauna (such as large bivalves) collected with a large core and sieved on 3-mm mesh (referred to as 3-mm infauna), and also to examine shallow-dwelling, small infauna (such as many polychaetes or recruits of larger infauna) collected with a small, hand-held core and sieved on 500$\mu \mathrm{m}$ mesh (referred to as 500- $\mu \mathrm{m}$ infauna). Deep-dwelling macrofauna were collected using a benthic suction sampler (Orth and van Montfrans 1987, Eggleston et al. 1992). A large, 38-cm diam $\left(0.11-\mathrm{m}^{2}\right)$ PVC core was inserted into the sediment to a depth of approximately $30 \mathrm{~cm}$, sediment and animals inside were removed by suction, and material was sieved in the field. To capture the smaller fraction of the infaunal community in the surface layer $\left(<10-\mathrm{cm}\right.$ depth), a small, $12-\mathrm{cm}$ diam $\left(0.011-\mathrm{m}^{2}\right)$ push core was taken to approximately $10-\mathrm{cm}$ depth. All 45 samples were processed for the 3-mm infauna, but due to logistical constraints, only 21 randomly selected $500-\mu \mathrm{m}$ infauna samples (seven per shoreline type) were processed. All samples were transferred to $70 \%$ ethanol, stained with Rose Bengal vital stain, and sorted under a dissecting microscope. All infaunal organisms were identified to the lowest possible taxonomic level (usually species). PRIMER v6 was used to calculate Shannon diversity $\left(\mathrm{H}^{\prime} \log _{\mathrm{e}}\right)$. Infauna were dried for $48 \mathrm{hrs}$ at $70^{\circ} \mathrm{C}$ and then ashed in a muffle furnace for six $\mathrm{h}$ at $550{ }^{\circ} \mathrm{C}$ to obtain ash-free dry weights (AFDW $\mathrm{g} \mathrm{m}^{-2}$; bulk weight taxa per site).

We also assessed infaunal feeding guilds at each shoreline type. Organisms were grouped into one of the following categories to develop an overview of the community: deposit feeder, suspension feeder, or carnivore/omnivore, based on literature descriptions (see Online Table 1). Although the polychaete Alitta (formerly Neanthes) succinea (Leuckart, 1847) has been classified as both a surface deposit feeder and a carnivore/omnivore, the latter classification was used for our study to maintain consistency with standard Chesapeake Bay Program categorization (Weisberg et al. 1997).

Predators.-Mobile fish and crab predators were obtained using a small otter trawl (2-m wide, 4.9-m long, and 0.95-cm mesh). At each site, 2-min trawls were performed with and against the current, as near to $5 \mathrm{~m}$ offshore as water levels, obstructions, and tides would allow (generally $5-10 \mathrm{~m}$ ), and both trawls at a site were pooled. About $9 \%$ of pooled samples ( 4 of 45 sites) occurred at $>10$ m offshore due to obstructions (e.g., private docks, deployed fyke nets). Organisms collected were identified, measured in the field, and released, or placed in an ice slurry and taken back to the lab for species confirmation. The tidal range in the Patuxent River, generally 0.5-1.0 m (Boynton et al. 2008), ensured all sampling-both infauna and mobile predators-occurred subtidally.

\section{Statistical Analyses}

Data were analyzed first using logistic regression and an information theoretic (IT) approach (Burnham and Anderson 2002, Anderson 2008) with Akaike's information criterion $\left(\mathrm{AIC}_{\mathrm{c}}\right)$ to assess the fit of candidate models $\left(g_{i} ;\right.$ Table 1$)$ to the data with all three river zones combined to encompass natural variability along a salinity gradient. The IT approach does not rely on $P$ values (frequentist approach), but rather on 
Table 1. Explanatory variables and general linear model construction for each AIC calculation. Predictors contained in each model $(g)$ are indicated in parentheses. $\mathrm{K}=$ number of parameters in a given model $(g 1-g 10)$, including $\sigma^{2}$ and $\beta_{0} ; \mathrm{SL}=$ shoreline type; Sed = sediment type (percent sand + gravel $) ;$ Pred $=$ predator abundance; $\mathrm{RWE}=$ representative wave energy; TOC $=$ percent total organic carbon; $\mathrm{Chl}=$ sediment chloraphyll- $a$ concentration. For models containing shoreline type (i.e., $g 1, g 2, g 3, g 4), \beta_{0}$ is represented by natural marsh. The global model $(g 1)$ includes all explanatory parameters.

\begin{tabular}{lccccccccc}
\hline Model & $\mathrm{K}$ & $\begin{array}{c}\text { Constant } \\
\left(\beta_{0}\right)\end{array}$ & $\begin{array}{c}\text { Riprap } \\
\left(x_{1}\right)\end{array}$ & $\begin{array}{c}\text { Bulkhead } \\
\left(x_{2}\right)\end{array}$ & $\begin{array}{c}\text { Sed } \\
\left(x_{3}\right)\end{array}$ & $\begin{array}{c}\text { Pred } \\
\left(x_{4}\right)\end{array}$ & $\begin{array}{c}\text { RWE } \\
\left(x_{5}\right)\end{array}$ & $\begin{array}{c}\text { TOC } \\
\left(x_{6}\right)\end{array}$ & $\begin{array}{c}\text { Chl } \\
\left(x_{7}\right)\end{array}$ \\
\hline g1 (global) & 9 & $\beta_{0}$ & $\beta_{1}$ & $\beta_{2}$ & $\beta_{3}$ & $\beta_{4}$ & $\beta_{5}$ & $\beta_{6}$ & $\beta_{7}$ \\
g2 (SL+Sed+Pred) & 6 & $\beta_{0}$ & $\beta_{1}$ & $\beta_{2}$ & $\beta_{3}$ & $\beta_{4}$ & & & \\
g3 (SL) & 4 & $\beta_{0}$ & $\beta_{1}$ & $\beta_{2}$ & & & & & \\
g4 (SL+Sed) & 5 & $\beta_{0}$ & $\beta_{1}$ & $\beta_{2}$ & $\beta_{3}$ & & & & \\
g5 (Sed) & 3 & $\beta_{0}$ & & & $\beta_{3}$ & & & & \\
g6 (Pred) & 3 & $\beta_{0}$ & & & & $\beta_{4}$ & & & \\
g7(Sed+Pred) & 4 & $\beta_{0}$ & & & $\beta_{3}$ & $\beta_{4}$ & & & \\
g8 (RWE) & 3 & $\beta_{0}$ & & & & & $\beta_{5}$ & $\beta_{6}$ & \\
$g 9(\mathrm{TOC})$ & 3 & $\beta_{0}$ & & & & & & & $\beta_{7}$ \\
g10 (Chl) & 3 & $\beta_{0}$ & & & & & & &
\end{tabular}

the effect sizes, their precision, and goodness-of-fit statistics (Anderson 2008). This approach is not used to disprove null hypotheses, but rather to identify the most parsimonious explanation for the observed data (Burnham and Anderson 2002). In general, a parameter estimate with a 95\% confidence interval (approximately 2 SE) will yield similar conclusions as an $\alpha=0.05$ significance test, but the examination of effect sizes yields information about the biological importance of the results. We proposed a total of 10 models for each benthic data set (3-mm and 500- $\mu \mathrm{m}$ infauna), each model consisting of combinations of explanatory variables that were hypothesized to most strongly affect infaunal responses (Table 1), and parameter estimates for strong predictors were calculated (see Online Tables 2 and 3). Variables assessed included shoreline type, sediment type (\% sand + gravel; Seitz et al. 2006, Seitz and Lawless 2008), predator abundance, wave energy, TOC, and surface chl- $a$. Combinations of predictor variables in the model set (Table 1) were limited to those thought to most directly impact infauna (see above) and/or exhibit an interactive effect on one another. Shoreline was paired with sediment type in model g4 (Table 1) due to the potential for artificial structures to alter sediment via wave scour, etc. A model containing both sediment type and predator abundance $(g 7)$ was included to gauge any potential interactive effects of these two key drivers (separate from shoreline type). Because a model containing only shoreline type and predator abundance was included in the 2008 pilot work and did not emerge as a strong predictor of any community characteristic, it was excluded in the current study. Though some other predictive variables (e.g., TOC, wave energy) may be correlated with shoreline type, their inclusion in the $\mathrm{AIC}_{\mathrm{c}}$ model could lead to insights regarding the mechanisms producing differences by shoreline type. These "secondary" variables were included on their own in the model set (models $g 8$ and $g 9$; Table 1 ) to gain clarity as to their influence in benthic dynamics, as this is the first study in which they were included in such an assessment. Other factors measured in the field (e.g., salinity and DO) were not included in analyses, as they did not vary notably across the study area or by shoreline type. 
The relative strength of each model was determined by comparing individual $\mathrm{AIC}_{\mathrm{c}}$ values against the lowest $\mathrm{AIC}_{\mathrm{c}}$ in a model set $\left(\Delta_{\mathrm{i}}\right)$. Based on $\Delta \mathrm{AIC}_{\mathrm{c}}$ values, each model was assigned a weighted probability $\left(w_{i}\right)$, e.g., an estimate of the weight of evidence of model $g_{i}$ being the best in the candidate set. A $\Delta$ AIC ${ }_{c}$ less than approximately 2 or a weight of at least 0.10 was considered to indicate support for a model (Anderson et al. 2001). If a parameter was included in one or more of the likely models, it was considered a predictor of that response variable.

Before regression analysis, each response variable was evaluated for normality and homogeneity of variance (shoreline type as a grouping variable) through visual analysis of quartile-quartile plots (residuals) and a Bartlett test. Data were Box-Cox transformed where assumptions were not met. Analyses were completed using $R$ statistical software v2.7.2 and Minitab v16, and an independent $\mathrm{AIC}_{\mathrm{c}}$ analysis was conducted for each infaunal response variable.

To help further elucidate patterns in infaunal data by both shoreline and river zone, non-metric multi-dimensional scaling (nMDS) techniques were used separating the three river zones (up, mid, down) and examining community structure within and between shoreline types based on Bray-Curtis similarities calculated from non-transformed species abundance data (PRIMER v6; Clarke and Gorley 2006). Two-way crossed analysis of similarity tests (ANOSIM) on infaunal species abundance data were used to determine significant differences between shoreline types and river zones, and three outliers (one of each shoreline type) were removed before performing these tests. Bray-Curtis dissimilarity percentages were calculated on species abundance data between shoreline types using similarity percentage analysis (SIMPER). Similar analyses were performed on 500- $\mu$ m data, which were logtransformed to temper dominant species, allowing other mid-range and rare species to exert some influence on calculations of similarity (Clarke and Warwick 2001). One sample from the 500-micron infaunal data had an abundance of zero, skewing the remaining points so that they all laid atop one another and no trends could be discerned. The zero-abundance point was removed from further analyses so as to more clearly see the patterns of the remaining points. To analyze the distribution of feeding guilds by shoreline type alone for large and small infauna separately, we used an analysis of variance (ANOVA) by shoreline type with all three river zones combined. We also used correlation to examine predator densities compared to infaunal densities for both size fractions combined across all river zones and all three shoreline types.

\section{BAY-WIDE COMPARISONS}

To determine how our observations of infaunal communities in the Patuxent River compared with infaunal communities in other Chesapeake Bay tributaries, infaunal density, diversity $\left(\mathrm{H}^{\prime}\right)$, and biomass data from the Chesapeake Bay Program's (CBP) sampling in 1996-2006 (D Dauer, Old Dominion University, pers comm) were visually compared with our observed 2009 responses. To maintain consistency with CBP methods, only $500-\mu \mathrm{m}$ data from our study were considered. The CBP design and collection methods include stratified-random sampling of 250 sites $\mathrm{yr}^{-1}$ throughout Chesapeake Bay (excluding the central channel) in the summer using a Ponar grab $\left(0.044 \mathrm{~m}^{2}\right)$. Each sample is sieved on $500-\mu \mathrm{m}$ mesh, preserved in formalin, and organisms identified and enumerated (for more details, see Seitz et al. 2009). 
Table 2. Mean values (SE) of water quality, sediment, and wave energy measurements at each shoreline type. Chlorophyll (chl) values represent mean (SE) total surface chlorophyll (including chl- $a$ plus phaeophytin) from 0 to $3 \mathrm{~mm}$ depth. TOC $=$ total organic carbon; $\mathrm{TN}=$ total nitrogen; $\mathrm{RWE}=$ representative wave energy. For all parameters, $n=45$.

\begin{tabular}{lrrr}
\hline & Natural marsh & \multicolumn{1}{c}{ Riprap } & \multicolumn{1}{c}{ Bulkhead } \\
\hline Temperature $\left({ }^{\circ} \mathrm{C}\right)$ & $27.25(0.41)$ & $27.09(0.28)$ & $27.34(0.30)$ \\
Salinity & $9.40(0.29)$ & $9.60(0.22)$ & $9.49(0.25)$ \\
Dissolved $\mathrm{O}_{2}\left(\mathrm{mg} \mathrm{L}^{-1}\right)$ & $6.92(0.30)$ & $7.48(0.28)$ & $7.13(0.32)$ \\
Percent sand + gravel $_{\text {Chlorophyll }\left(\mu \mathrm{g} \mathrm{cm}^{-2}\right)}$ & $72.15(8.17)$ & $91.02(4.75)$ & $89.51(3.72)$ \\
Percent TOC & $6.31(0.81)$ & $10.99(2.09)$ & $10.37(4.23)$ \\
Percent TN & $2.59(1.13)$ & $0.16(0.01)$ & $0.21(0.06)$ \\
RWE $\left(\mathrm{J} \mathrm{m}^{-1}\right)$ & $0.19(0.07)$ & $0.02(0.00)$ & $0.03(0.01)$ \\
\hline
\end{tabular}

\section{RESULTS}

\section{Water Quality, Sediment, And Wave Energy}

Water quality parameters (temperature, salinity, DO) differed little among shoreline types (Table 2). Both TOC and total nitrogen (TN) tended to be greater adjacent to marsh than to riprap or bulkhead and ranged from $0.10 \%$ to $14.32 \%$ for TOC, and $0.01 \%$ to $0.86 \%$ for TN. TOC and TN were highly correlated with one another $\left(R^{2}=\right.$ $0.98, P<0.0005)$ and also were inversely correlated with sediment grain size $\left(R^{2}=\right.$ $0.28, P=0.0001 ; 0.36, P<0.0005$; respectively), as in similar studies (Lawless and Seitz 2014). Due to the high correlation between TOC and TN, only TOC was used in regression models. Sediment grain size (percent sand + gravel) tended to be highest adjacent to riprap and lowest adjacent to marsh and was generally coarse, with the mean among all sites rarely falling below $50 \%$ sand + gravel. Mean total surface chl ranged from 0.45 to $68.50 \mu \mathrm{g} \mathrm{cm}^{-2}$, was high adjacent to riprap, and was low adjacent to marsh. Representative wave energy (RWE) ranged from 10 to $184 \mathrm{~J} \mathrm{~m}^{-1}$. The highest mean RWE values tended to be associated with riprap, with intermediate values at bulkhead, and lowest at marsh (Table 2).

\section{INFAUNA (3-MM)}

For the larger infauna, 14 benthic species were collected across all sites. Bivalves were the numerically dominant taxa ( 8 species), followed by polychaetes (4 species) and crustaceans (2 species). Limecola (formerly Macoma) balthica (see Table 3 for species authorities) and Gemma gemma were the most numerically prevalent bivalves, while Alitta succinea was the most numerically prevalent polychaete (Table 3). Bivalves were biomass dominants (75\% of biomass across all shoreline types), while polychaetes were $4.3 \%$ and crustaceans $0.09 \%$ of the overall biomass.

Patterns in density, diversity, and biomass differed by shoreline type (Fig. 2). Mean infaunal density tended to be high adjacent to riprap, and was approximately 3 times greater than that of marsh, where density tended to be low, but variability was high (Fig. 2A). This was driven by densities of the clam G. gemma, which were particularly high adjacent to riprap and bulkhead. Mean diversity tended to be greater at bulkhead than natural marsh, and each exhibited approximately 1.5 to 2 times the diversity associated with riprap (Fig. 2B). The lowest mean biomass was associated with bulkhead, which was approximately 1.5 to 2.5 times lower than that at either 
Table 3. Species-specific 3-mm infaunal densities (individuals $\mathrm{m}^{-2}$, SE in parentheses) across three shoreline types. Abbreviations for feeding modes ("feeding") are as follows: SD = surface deposit feeder; SF = suspension feeder; $\mathrm{O}=$ omnivore; $\mathrm{C}=$ carnivore; $\mathrm{BD}=$ subsurface deposit feeder (Wilcox and Jeffries 1974, Fauchauld and Jumars 1979, Rader 1984, Bianchi and Rice 1988, Ruppert and Fox 1988, Diaz and Schaffner 1990, Hentschel 1998, Cunha et al. 2000).

\begin{tabular}{|c|c|c|c|c|}
\hline Species & Feeding & Natural marsh & Riprap & Bulkhead \\
\hline \multicolumn{5}{|l|}{ Bivalves } \\
\hline Limecola balthica (Linnaeus, 1758) & $\mathrm{SD}, \mathrm{SF}$ & $109.7(30.8)$ & $133.9(76.4)$ & $87.3(38.3)$ \\
\hline Ameritella mitchelli (Dall, 1895) & $\mathrm{SD}, \mathrm{SF}$ & $18.8(7.4)$ & $45.5(38.6)$ & $19.4(14.9)$ \\
\hline Macoploma tenta (Say, 1838) & $\mathrm{SD}, \mathrm{SF}$ & 0.0 & $0.6(0.6)$ & 0.0 \\
\hline Mya arenaria Linnaeus, 1758 & SF & $14.5(9.7)$ & $10.3(9.7)$ & $44.2(21.7)$ \\
\hline Mulinia lateralis (Say, 1822) & SF & $3.0(1.5)$ & $4.2(3.1)$ & $9.1(4.1)$ \\
\hline Gemma gemma (Totten, 1834) & SF & $7.9(6.7)$ & $266.1(119.0)$ & $235.8(121.0)$ \\
\hline Rangia cuneata (G. B. Sowerby I, 1832) & SF & $0.6(0.6)$ & 0.0 & $1.2(1.2)$ \\
\hline Tagelus plebeius (Lightfoot, 1786) & SF & 0.0 & $0.6(0.6)$ & $2.4(1.4)$ \\
\hline \multicolumn{5}{|l|}{ Polychaetes } \\
\hline Alitta succinea (Leuckart, 1847) & $\mathrm{SD}, \mathrm{O}$ & $32.1(20.9)$ & $77.6(57.7)$ & $63.6(38.7)$ \\
\hline Laeonereis culveri (Webster, 1879) & $\mathrm{SD}, \mathrm{O}$ & $1.2(1.2)$ & 0.0 & 0.0 \\
\hline Glycera dibranchiata Ehlers, 1868 & $\mathrm{C}, \mathrm{BD}$ & $9.7(9.7)$ & 0.0 & 0.0 \\
\hline Leitoscoloplos spp. & $\mathrm{BD}$ & 0.0 & 0.0 & $3.0(3.0)$ \\
\hline \multicolumn{5}{|l|}{ Crustacea } \\
\hline Crangon septemspinosa Say, 1818 & $\mathrm{C}, \mathrm{O}$ & $0.6(0.6)$ & 0.0 & $0.6(0.6)$ \\
\hline Misc. decapod & & $0.6(0.6)$ & 0.0 & 0.0 \\
\hline Total & & $199.0(50.3)$ & $539.0(206.0)$ & $467.0(158.0)$ \\
\hline
\end{tabular}

riprap or marsh, respectively (Fig. $2 \mathrm{C}$ ). In the $\mathrm{AIC}_{\mathrm{c}}$ model comparison, the model containing only RWE ( $g 8$ ) was strongly supported by the $3-\mathrm{mm}$ density data (i.e., this model received the highest weight), though the model containing chl ( $g 10)$ also had strong support (Table 4, Online Tables 2 and 3). The model containing shoreline type only $(g 3)$ received highest support by diversity data, although models with chl only ( $g 10)$, \% TOC only ( $g 9$ ), and predator abundance only ( $g 6)$ also had strong support (Table 5, Online Tables 1 and 2). AIC ${ }_{c}$ models containing sediment type and predator abundance [both alone $(g 5)$ and with sediment type $(g 7)$ ] were strongly supported by the biomass data (Table 6, Online Table 1 and 2).

ANOSIM tests based on nMDS plots revealed a similar degree of variability in 3-mm community structure within each shoreline type as among the three shoreline types (Global $\mathrm{R}=0.175 ; P=0.006$; Clarke and Gorley 2006). Although river zone did not emerge as a strong predictor of infauna in $\mathrm{AIC}_{\mathrm{c}}$ analyses (post-hoc $\mathrm{AIC}_{\mathrm{c}}$, not shown), ANOSIM tests comparing up-, mid-, and downriver sites revealed differences in community structure, suggesting large-scale differences in the tributary (Global $\mathrm{R}=0.347 ; P=0.001$ ) (Fig. 3A). In the SIMPER analysis based on this Global $R$ value (Clarke and Warwick 2001), average dissimilarity between pairs of zones was largely driven by the one of the most common bivalves, G. gemma (Fig. 3B), with upriver sites having lower densities and being clearly distinguishable from mid-river $($ dissimilarity $=83.19 \%)$ and downriver (dissimilarity $=81.86 \%)$.

INFAUNA $(500-\mu \mathrm{m})$

For the smaller infauna, across 21 sites, 29 species were collected. Polychaetes were the numerically dominant taxa ( 14 species), followed by crustaceans ( 9 species) and 

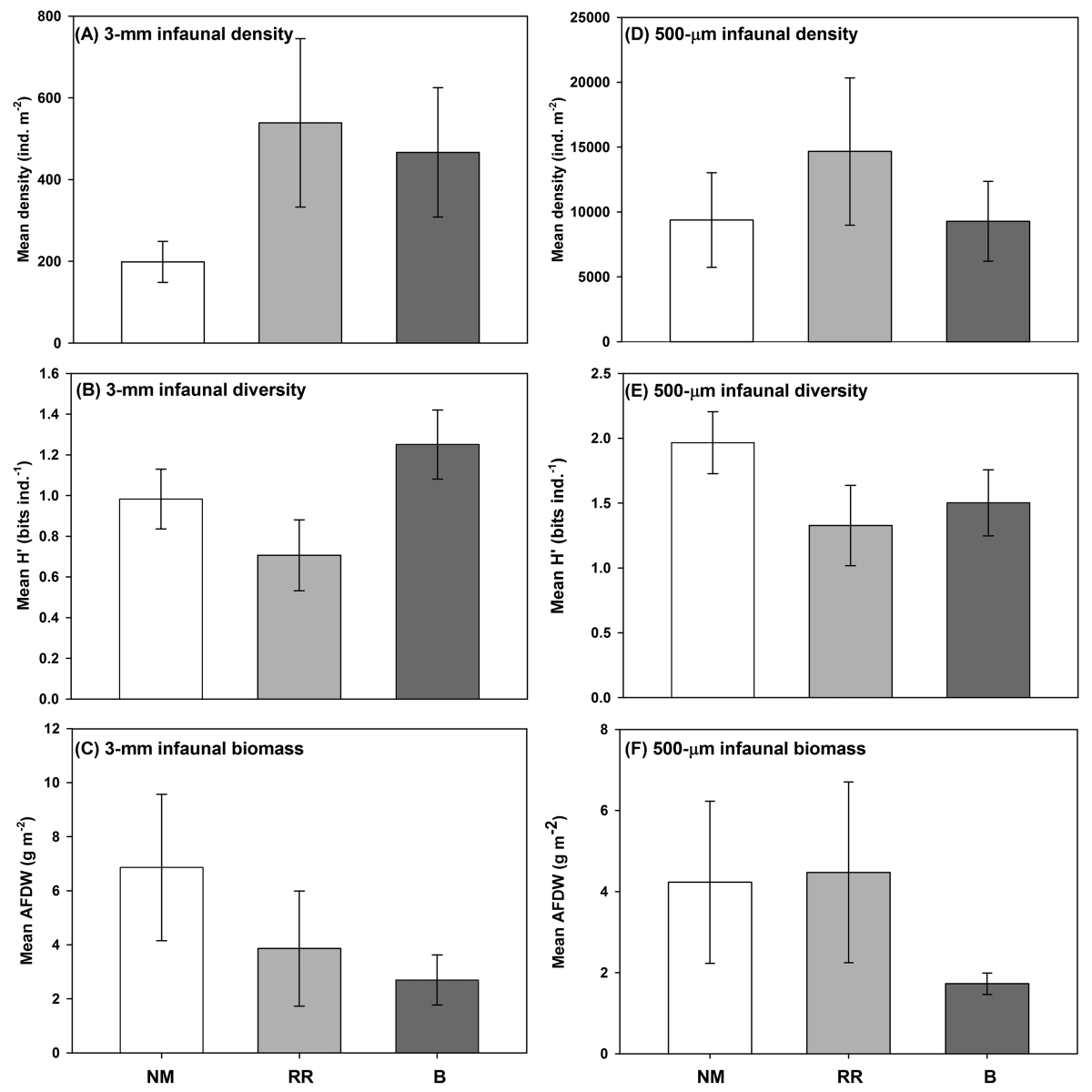

Shoreline type

Figure 2. Shoreline effects on mean $( \pm \mathrm{SE})(\mathrm{A}) 3-\mathrm{mm}$ infaunal density, (B) Shannon diversity, and (C) biomass, and (D) 500- $\mathrm{m}$ infaunal density, (E) Shannon diversity, and (F) biomass. Shoreline type: $\mathrm{NM}=$ natural marsh, $\mathrm{RR}=$ riprap, $\mathrm{B}=$ bulkhead.

bivalves (6 species). Alitta succinea and Leptocheirus plumulosus Shoemaker, 1932 were the most abundant polychaete and crustacean, respectively, while G. gemma and Mya arenaria made up a majority of the bivalves. Bivalves made up the greatest percentage of total biomass at approximately $53 \%$, while polychaetes made up around $24 \%$ and crustaceans around $7.5 \%$ (species list for $500-\mu \mathrm{m}$ infauna: Online Table 1). Similar to 3-mm infauna, 500- $\mu \mathrm{m}$ infauna differed slightly among shoreline types (Fig. 2). Mean density tended to be high adjacent to riprap, and low adjacent to bulkhead, and variation was high. Both marsh and bulkhead supported a mean density that was approximately 1.5 times lower than riprap (Fig. 2D). Diversity tended to be high at marsh and, similar to 3-mm infauna, low at riprap (Fig. 2E). The lowest mean biomass occurred at bulkhead (Fig. 2F), and was approximately 2 times lower than at riprap or marsh.

In the $\mathrm{AIC}_{\mathrm{c}}$ analysis, models $g 10$ and $g 8$, containing chl and RWE, respectively, were strongly supported by the $500-\mu \mathrm{m}$ infaunal density data (Table 7, Online Tables 
Table 4. AIC $\mathrm{c}_{\mathrm{c}}$ results for 3-mm infaunal density. Rows with bolded text indicate models with strong support (weighted values $\geq 0.10$ ). Abbreviations are as in Table 1. Weights (probabilities) are indicated with $\mathrm{w}_{\mathrm{i}}$. See Online Tables 2 and 3 for parameter estimates.

\begin{tabular}{lcccccc}
\hline Model & Log-likelihood & $\mathrm{K}$ & $\mathrm{AIC}_{\mathrm{c}}$ & $\Delta \mathrm{AIC}_{\mathrm{c}}$ & $\mathrm{w}_{\mathrm{i}}$ & $R^{2}$ \\
\hline g8 (RWE) & $\mathbf{- 1 2 5 . 7 0}$ & $\mathbf{3}$ & $\mathbf{2 5 7 . 4 1}$ & $\mathbf{0 . 0 0}$ & $\mathbf{0 . 5 2 4}$ & $\mathbf{0 . 0 5 0}$ \\
g10 (Chl) & $-\mathbf{1 2 6 . 9 9}$ & $\mathbf{3}$ & $\mathbf{2 5 9 . 9 9}$ & $\mathbf{2 . 5 8}$ & $\mathbf{0 . 1 4 4}$ & $\mathbf{0 . 0 1 8}$ \\
g5 (Sed) & -127.54 & 3 & 261.09 & 3.68 & 0.083 & 0.006 \\
g6 (Pred) & -127.77 & 3 & 261.53 & 4.12 & 0.067 & 0.025 \\
g9 (TOC) & -127.76 & 3 & 261.51 & 4.10 & 0.067 & 0.006 \\
g3 (SL) & -126.89 & 4 & 261.77 & 4.78 & 0.048 & 0.061 \\
g4 (SL+Sed) & -126.09 & 5 & 262.18 & 5.73 & 0.030 & 0.061 \\
g7 (Sed+Pred) & -127.52 & 4 & 263.04 & 6.05 & 0.025 & 0.025 \\
g2 (SL+Sed+Pred) & -126.09 & 6 & 264.18 & 8.40 & 0.008 & 0.072 \\
g1(SL+Sed+Pred+RWE+TOC+Chl) & -122.45 & 9 & 262.89 & 10.04 & 0.003 & 0.116 \\
\hline
\end{tabular}

2 and 3). Additionally, the model with sediment type ( $g 5)$ had strong support by the density data, with greater densities occurring with lower percentage sand + gravel. AIC models $g 10$ and $g 8$ (chl and RWE) were the top-ranking models for $500-\mu \mathrm{m}$ infaunal diversity (Table 8, Online Tables 2 and 3). As with the 3-mm infauna, predator abundance $(g 6)$, sediment type $(g 5)$, and both variables together $(g 7)$ were strongly supported by the $500-\mu \mathrm{m}$ infaunal biomass data. Unlike the larger size fraction, the model containing \%TOC alone $(g 9)$ also had strong support by the biomass data (Table 9, Online Tables 2 and 3).

In multivariate (nMDS) analyses on 500- $\mu$ m infauna, results were similar to those for 3-mm infauna indicating comparable within-site vs among-site variability (Fig. 4A). Both dissimilarity and species contribution percentages in a SIMPER analysis were low ( $<65 \%$ and $<15 \%$, respectively). Gemma gemma still appeared to drive the strongest trend in zone differences, contributing $11 \%$ to differences among up- and downriver sites (Fig. 4B).

\section{INFAUNAL COMMUNiTy COMPOSITION}

In both $3-\mathrm{mm}$ and $500-\mu \mathrm{m}$ infauna, there were no significant differences in the distribution of feeding modes among the three shoreline types (ANOVA: all Ps > 0.05; Fig. 5A, B). There was a trend toward more carnivores, omnivores, and deposit feeders adjacent to natural marshes compared to riprap or bulkhead shorelines.

Table 5. AIC $\mathrm{c}_{\mathrm{c}}$ results for 3-mm infaunal diversity. Rows with bolded text indicate models with strong support (weighted values $\geq 0.10$ ). Abbreviations are as in Table 1 . Weights (probabilities) are indicated with $\mathrm{w}_{\mathrm{i}}$. See Online Tables 2 and 3 for parameter estimates.

\begin{tabular}{lcccccc}
\hline Model & Log-likelihood & $\mathrm{K}$ & $\mathrm{AIC}_{\mathrm{c}}$ & $\Delta \mathrm{AIC}_{\mathrm{c}}$ & $\mathrm{w}_{\mathrm{i}}$ & $R^{2}$ \\
\hline g3 (SL) & $\mathbf{- 4 1 . 9 3}$ & $\mathbf{4}$ & $\mathbf{9 1 . 8 6}$ & $\mathbf{0 . 0 0}$ & $\mathbf{0 . 3 2 2}$ & $\mathbf{0 . 1 1 6}$ \\
g10 (Chl) & $-\mathbf{4 4 . 0 1}$ & $\mathbf{3}$ & $\mathbf{9 4 . 0 3}$ & $\mathbf{1 . 7 6}$ & $\mathbf{0 . 1 3 4}$ & $\mathbf{0 . 0 3 0}$ \\
g9 (TOC) & $-\mathbf{4 4 . 1 7}$ & $\mathbf{3}$ & $\mathbf{9 4 . 3 3}$ & $\mathbf{2 . 0 6}$ & $\mathbf{0 . 1 1 5}$ & $\mathbf{0 . 0 2 4}$ \\
g6 (Pred) & $-\mathbf{4 4 . 2 5}$ & $\mathbf{3}$ & $\mathbf{9 4 . 5 0}$ & $\mathbf{2 . 2 3}$ & $\mathbf{0 . 1 0 5}$ & $\mathbf{0 . 0 2 0}$ \\
g4 (SL+Sed) & -41.92 & 5 & 93.85 & 2.53 & 0.091 & 0.116 \\
g8 (RWE) & -44.42 & 3 & 94.83 & 2.56 & 0.089 & 0.012 \\
g5 (Sed) & -44.69 & 3 & 95.37 & 3.10 & 0.068 & 0.000 \\
g2 (SL+Sed+Pred) & -41.46 & 6 & 94.92 & 4.28 & 0.038 & 0.134 \\
g7 (Sed+Pred) & -44.13 & 4 & 96.26 & 4.41 & 0.036 & 0.025 \\
g1(SL+Sed+Pred+RWE+TOC+Chl) & -39.37 & 9 & 96.74 & 9.03 & 0.004 & 0.211 \\
\hline
\end{tabular}


Table 6. AIC results for 3-mm infaunal biomass. Rows with bolded text indicate models with strong support (weighted values $\geq 0.10$ ). Abbreviations are as in Table 1. Weights (probabilities) are indicated with $\mathrm{w}_{\mathrm{i}}$. See Online Tables 2 and 3 for parameter estimates.

\begin{tabular}{lcccccc}
\hline Model & Log-likelihood & $\mathrm{K}$ & $\mathrm{AIC}_{\mathrm{c}}$ & $\Delta \mathrm{AIC}_{\mathrm{c}}$ & $\mathrm{w}_{\mathrm{i}}$ & $R^{2}$ \\
\hline g5 (Sed) & $\mathbf{- 2 9 . 5 3}$ & $\mathbf{3}$ & $\mathbf{6 5 . 0 6}$ & $\mathbf{0 . 0 0}$ & $\mathbf{0 . 3 9 2}$ & $\mathbf{0 . 0 3 5}$ \\
g7 (Sed+Pred) & $\mathbf{- 2 8 . 9 6}$ & $\mathbf{4}$ & $\mathbf{6 5 . 9 3}$ & $\mathbf{1 . 3 0}$ & $\mathbf{0 . 2 0 5}$ & $\mathbf{0 . 0 8 5}$ \\
g6 (Pred) & $-\mathbf{3 0 . 3 1}$ & $\mathbf{3}$ & $\mathbf{6 6 . 6 3}$ & $\mathbf{1 . 5 8}$ & $\mathbf{0 . 1 7 8}$ & $\mathbf{0 . 0 7 5}$ \\
g10(Chl) & -31.58 & 3 & 69.15 & 4.09 & 0.051 & 0.002 \\
g8 (RWE) & -31.59 & 3 & 69.17 & 4.11 & 0.050 & 0.038 \\
g9 (TOC) & -31.66 & 3 & 69.31 & 4.24 & 0.047 & 0.000 \\
g4 (SL+Sed) & -29.40 & 5 & 68.79 & 4.68 & 0.038 & 0.064 \\
g2 (SL+Sed+Pred) & -28.72 & 6 & 69.44 & 5.99 & 0.020 & 0.102 \\
g3 (SL) & -31.41 & 4 & 70.82 & 6.16 & 0.018 & 0.049 \\
g1(SL+Sed+Pred+RWE+TOC+Chl) & -27.01 & 9 & 72.02 & 11.52 & 0.001 & 0.170 \\
\hline
\end{tabular}
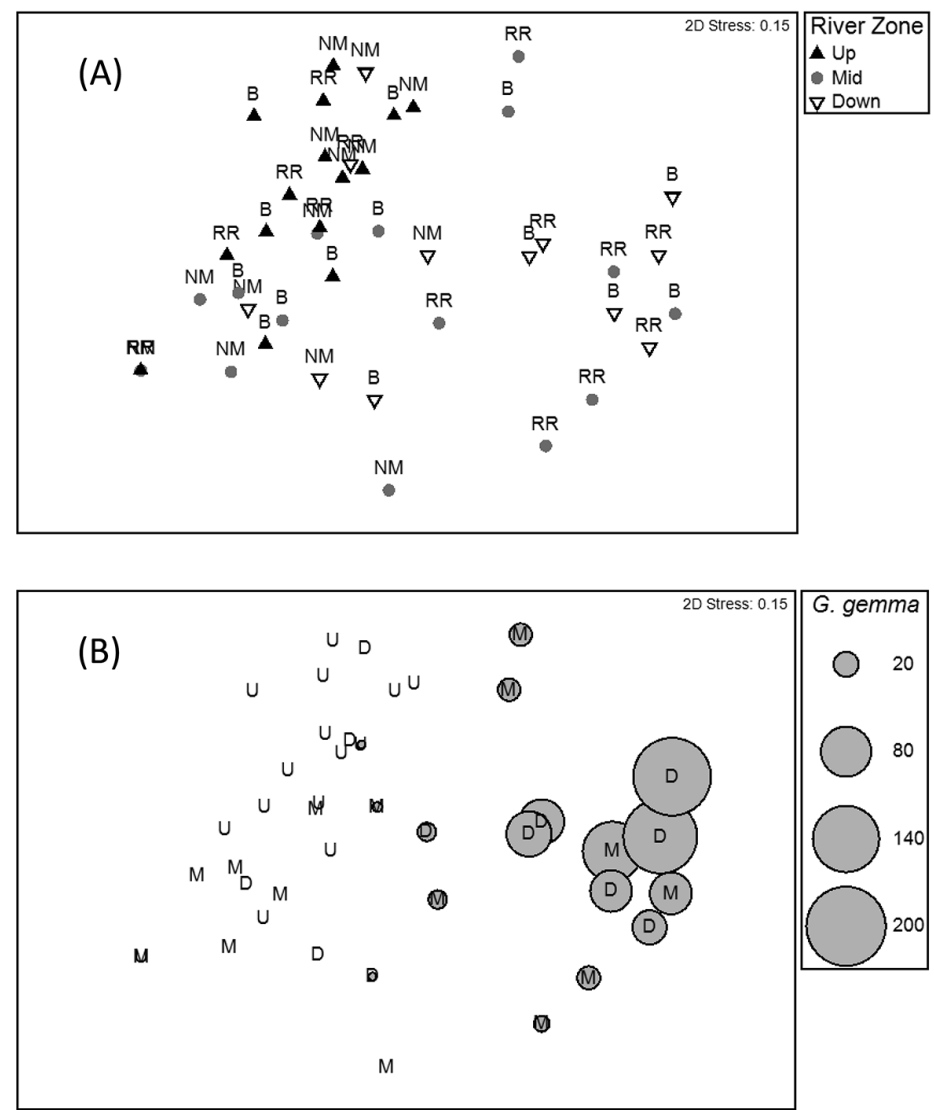

Figure 3. (A) Non-metric multi-dimensional scaling (nMDS) plot based on Bray-Curtis similarity test on non-transformed 3-mm infaunal data. Upriver sites are represented with black triangles, mid-river with gray circles, and downriver with white triangles. Site labels indicate shoreline type $($ bulkhead $=\mathrm{B}$, riprap $=\mathrm{RR}$, marsh $=\mathrm{NM}$ ). (B) Bubble plot of Gemma gemma density from 3-mm infaunal data across sampling sites within the three river zones of the study area with river zone indicated $(\mathrm{U}=$ upriver, $\mathrm{M}=$ mid-river, $\mathrm{D}=$ downriver). The size of the circles indicates the relative density of $G$. gemma. Average dissimilarity was lowest between mid- and downriver sites $(74.54 \%)$. 
Table 7. AIC results for 500- $\mu \mathrm{m}$ infaunal density. Rows with bolded text indicate models with strong support (weighted values $\geq 0.10$ ). Abbreviations are as in Table 1 . Weights (probabilities) are indicated with $\mathrm{w}_{\mathrm{i}}$. See Online Tables 2 and 3 for parameter estimates.

\begin{tabular}{lcccccc}
\hline Model & Log-likelihood & $\mathrm{K}$ & $\mathrm{AIC}_{\mathrm{c}}$ & $\Delta \mathrm{AIC}_{\mathrm{c}}$ & $\mathrm{w}_{\mathrm{i}}$ & $R^{2}$ \\
\hline g10 (Chl) & $\mathbf{- 5 4 . 1 3}$ & $\mathbf{3}$ & $\mathbf{1 1 4 . 2 6}$ & $\mathbf{0 . 0 0}$ & $\mathbf{0 . 4 5 5}$ & $\mathbf{0 . 1 4 2}$ \\
g5 (Sed) & $\mathbf{- 5 5 . 0 9}$ & $\mathbf{3}$ & $\mathbf{1 1 6 . 1 8}$ & $\mathbf{1 . 9 3}$ & $\mathbf{0 . 1 7 4}$ & $\mathbf{0 . 0 8 8}$ \\
g8 (RWE) & $-\mathbf{5 5 . 5 1}$ & $\mathbf{3}$ & $\mathbf{1 1 7 . 0 1}$ & $\mathbf{2 . 7 5}$ & $\mathbf{0 . 1 1 5}$ & $\mathbf{0 . 0 8 8}$ \\
g9 (TOC) & -55.80 & 3 & 117.59 & 3.33 & 0.086 & 0.028 \\
g6 (Pred) & -56.12 & 3 & 118.24 & 3.98 & 0.062 & 0.007 \\
g4 (SL+Sed) & -53.25 & 5 & 116.50 & 4.83 & 0.041 & 0.215 \\
g7 (Sed+Pred) & -55.08 & 4 & 118.15 & 4.98 & 0.038 & 0.088 \\
g3 (SL) & -55.54 & 4 & 119.09 & 5.92 & 0.024 & 0.054 \\
g2 (SL+Sed+Pred) & -53.25 & 6 & 118.50 & 8.83 & 0.006 & 0.215 \\
g1(SL+Sed+Pred+RWE+TOC+Chl) & -50.38 & 9 & 118.76 & 19.46 & 0.000 & 0.442 \\
\hline
\end{tabular}

\section{Predators}

Across all sites, 17 species of benthic predators were collected. The highest mean abundance (catch per unit effort) of predators tended to be associated with natural marsh, which supported approximately twice the mean abundance of either riprap or bulkhead (Table 10), though variability precluded significant differences. We did detect a significant positive correlation between infaunal biomass and predator abundance in both size fractions across all shoreline types (e.g., $500-\mu \mathrm{m}: y=0.094 x+2.71$, $R^{2}=0.28, P=0.014$; back-transformed data).

\section{BAY-WIDE COMPARISONS}

Comparisons of our $2009500-\mu \mathrm{m}$ infaunal data and a collection of benthic data gathered over 11 yrs (1996-2006) by the Chesapeake Bay Program (CBP) puts our sampling in broader context. While the range in density for the Patuxent River over 11 yrs was among the lowest of the bay tributaries in the CBP sampling (see PXR in Fig. 6A), the 2009 mean for our 500- $\mu$ m samples (collected with slightly different methods) was markedly greater than many of the CBP-defined strata over the 11-yr period (Fig. 6A), possibly reflective of the recruitment of G. gemma in our samples. The diversity observed in the Patuxent River 11-yr mean from CBP samples was

Table 8. AIC $_{\mathrm{c}}$ results for $500-\mu \mathrm{m}$ infaunal diversity. Rows with bolded test indicate models with strong support (weighted values $\geq 0.10$ ). Abbreviations are as in Table 1 . Weights (probabilities) are indicated with $\mathrm{w}_{\mathrm{i}}$. See Online Tables 2 and 3 for parameter estimates.

\begin{tabular}{lcccccc}
\hline Model & Log-likelihood & $\mathrm{K}$ & $\mathrm{AIC}_{\mathrm{c}}$ & $\Delta \mathrm{AIC}_{\mathrm{c}}$ & $\mathrm{w}_{\mathrm{i}}$ & $R^{2}$ \\
\hline g10 (Chl) & $\mathbf{- 1 9 . 3 3}$ & $\mathbf{3}$ & $\mathbf{4 4 . 6 7}$ & $\mathbf{0 . 0 0}$ & $\mathbf{0 . 6 5 6}$ & $\mathbf{0 . 2 7 3}$ \\
g8 (RWE) & $-\mathbf{2 0 . 3 7}$ & $\mathbf{3}$ & $\mathbf{4 6 . 7 3}$ & $\mathbf{2 . 0 7}$ & $\mathbf{0 . 2 3 3}$ & $\mathbf{0 . 1 9 8}$ \\
g9 (TOC) & -22.59 & 3 & 51.18 & 6.52 & 0.025 & 0.009 \\
g3 (SL) & -21.06 & 4 & 50.12 & 6.55 & 0.025 & 0.143 \\
g5 (Sed) & -22.67 & 3 & 51.35 & 6.68 & 0.023 & 0.001 \\
g6 (Pred) & -22.68 & 3 & 51.35 & 6.69 & 0.023 & 0.001 \\
g4 (SL+Sed) & -20.46 & 5 & 50.91 & 8.84 & 0.008 & 0.191 \\
g7 (Sed+Pred) & -22.66 & 4 & 53.31 & 9.74 & 0.005 & 0.003 \\
g2 (SL+Sed+Pred) & -20.44 & 6 & 52.88 & 12.80 & 0.001 & 0.193 \\
g1(SL+Sed+Pred+RWE+TOC+Chl) & -15.26 & 9 & 48.51 & 18.80 & 0.000 & 0.507 \\
\hline
\end{tabular}


Table 9. AIC results for 500- $\mu \mathrm{m}$ infaunal biomass. Rows with bolded text indicate models with strong support (weighted values $\geq 0.10$ ). Abbreviations are as in Table 1 . Weights (probabilities) are indicated with $\mathrm{w}_{\mathrm{i}}$. See Online Tables 2 and 3 for parameter estimates.

\begin{tabular}{lrrrrrc}
\hline Model & Log-likelihood & $\mathrm{K}$ & $\mathrm{AIC}_{\mathrm{c}}$ & $\Delta \mathrm{AIC}_{\mathrm{c}}$ & $\mathrm{w}_{\mathrm{i}}$ & $R^{2}$ \\
\hline g6 (Pred) & $-\mathbf{1 . 6 8}$ & $\mathbf{3}$ & $\mathbf{9 . 3 6}$ & $\mathbf{0 . 0 0}$ & $\mathbf{0 . 4 3 0}$ & $\mathbf{0 . 2 8 0}$ \\
g5 (Sed) & $-\mathbf{2 . 7 6}$ & $\mathbf{3}$ & $\mathbf{1 1 . 5 2}$ & $\mathbf{2 . 1 6}$ & $\mathbf{0 . 1 4 6}$ & $\mathbf{0 . 1 0 2}$ \\
g7 (Sed+Pred) & $-\mathbf{1 . 3 9}$ & $\mathbf{4}$ & $\mathbf{1 0 . 7 8}$ & $\mathbf{2 . 5 0}$ & $\mathbf{0 . 1 2 3}$ & $\mathbf{0 . 3 0 7}$ \\
g9 (TOC) & $-\mathbf{3 . 0 9}$ & $\mathbf{3}$ & $\mathbf{1 2 . 1 8}$ & $\mathbf{2 . 8 2}$ & $\mathbf{0 . 1 0 5}$ & $\mathbf{0 . 0 7 1}$ \\
g10(Chl) & -3.36 & 3 & 12.71 & 3.35 & 0.080 & 0.000 \\
g8 (RWE) & -3.46 & 3 & 12.92 & 3.56 & 0.073 & 0.001 \\
g3 (SL) & -3.12 & 4 & 14.25 & 5.98 & 0.022 & 0.078 \\
g4 (SL+Sed) & -1.92 & 5 & 13.84 & 7.06 & 0.013 & 0.179 \\
g2 (SL+Sed+Pred) & -0.32 & 6 & 12.63 & 7.86 & 0.008 & 0.362 \\
g1(SL+Sed+Pred+RWE+TOC+Chl) & -0.14 & 9 & 18.28 & 23.87 & 0.000 & 0.412 \\
\hline
\end{tabular}
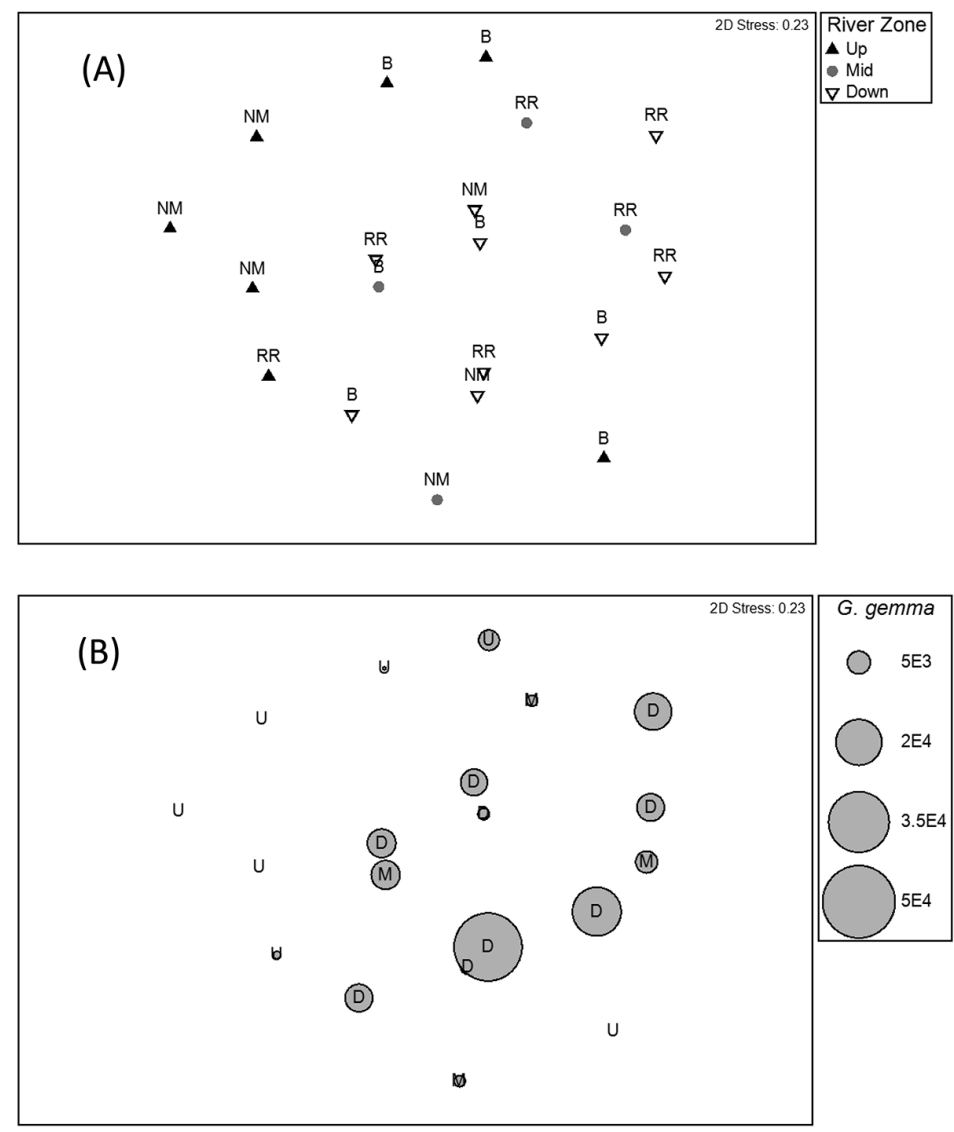

Figure 4. (A) Non-metric multi-dimensional scaling (nMDS) plot based on Bray-Curtis Similarity test on log-transformed 500- $\mu \mathrm{m}$ infaunal data. Upriver sites are represented with black triangles, mid-river with grey circles, and downriver with white triangles. Site labels indicate the shoreline type $($ bulkhead $=\mathrm{B}$, riprap $=\mathrm{RR}$, marsh $=\mathrm{NM})$. (B) Bubble plot of Gemma gemma abundance from 500- $\mu \mathrm{m}$ infaunal data across sampling sites within the three river zones of the study area ( $\mathrm{U}=$ upriver, $\mathrm{M}=$ mid-river, $\mathrm{D}=$ downriver). The size of the circles indicates the relative density of G. gemma, with "E" indicating the exponent to which the number is raised (e.g, 5E3=5000). Average dissimilarity was lowest between mid- and downriver sites (51.28\%). 


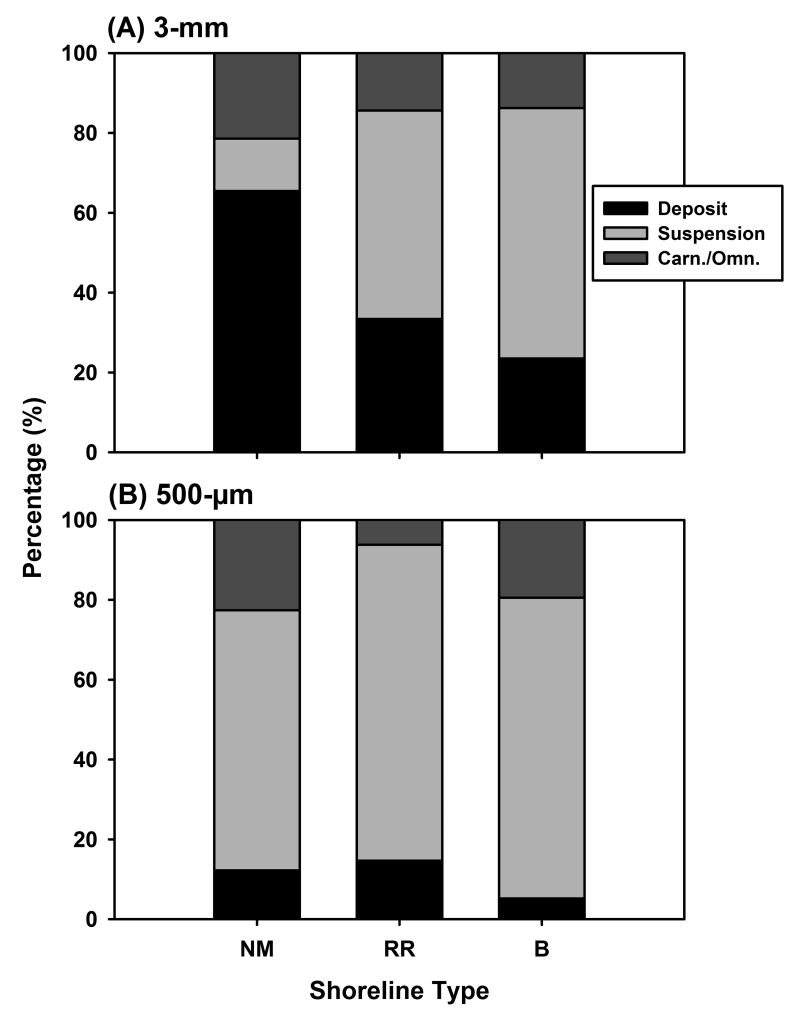

Figure 5. (A) Feeding mode distribution of 3-mm infauna and (B) $500-\mu \mathrm{m}$ infauna by shoreline type $(\mathrm{NM}=$ natural marsh, $\mathrm{RR}=$ riprap, $\mathrm{B}=$ bulkhead $)$.

among the three lowest when compared with other bay strata, and our $2009500-\mu \mathrm{m}$ infaunal mean diversity was lower than the CBP average for the Patuxent River (Fig. 6B). Mean CBP biomass in the Patuxent River was greater than the long-term mean for several strata, particularly those in the low- to mid-bay (Fig. 6C), while our 2009 $500-\mu \mathrm{m}$ infaunal biomass was lower than all strata assessed.

\section{Discussion}

We expected that benthic infauna would differ among natural and altered shorelines in the Patuxent River, based on previous work in more pristine subestuaries (Seitz et al. 2006, Lawless and Seitz 2014, Gittman et al. 2016), and we observed subtle differences in infaunal community characteristics amid high variation. Some of the most notable were the differences in infaunal diversity and feeding modes among shorelines. There were differences in deposit- vs suspension-feeding species, particularly G. gemma, between natural vs hardened shorelines. Gemma gemma tends to be patchily distributed (Jackson 1968, Commito et al. 1995) and the "snapshot" in time of our study may not reflect its typical abundance and may have resulted in high infaunal densities, particularly adjacent to riprap (where wave energy-RWEwas highest). Bulkhead and riprap shorelines tended to overwhelmingly support this and similar suspension-feeding species relative to natural marsh habitats. Where sediments were finest (e.g., marshes), there may have been feeding inhibition from 


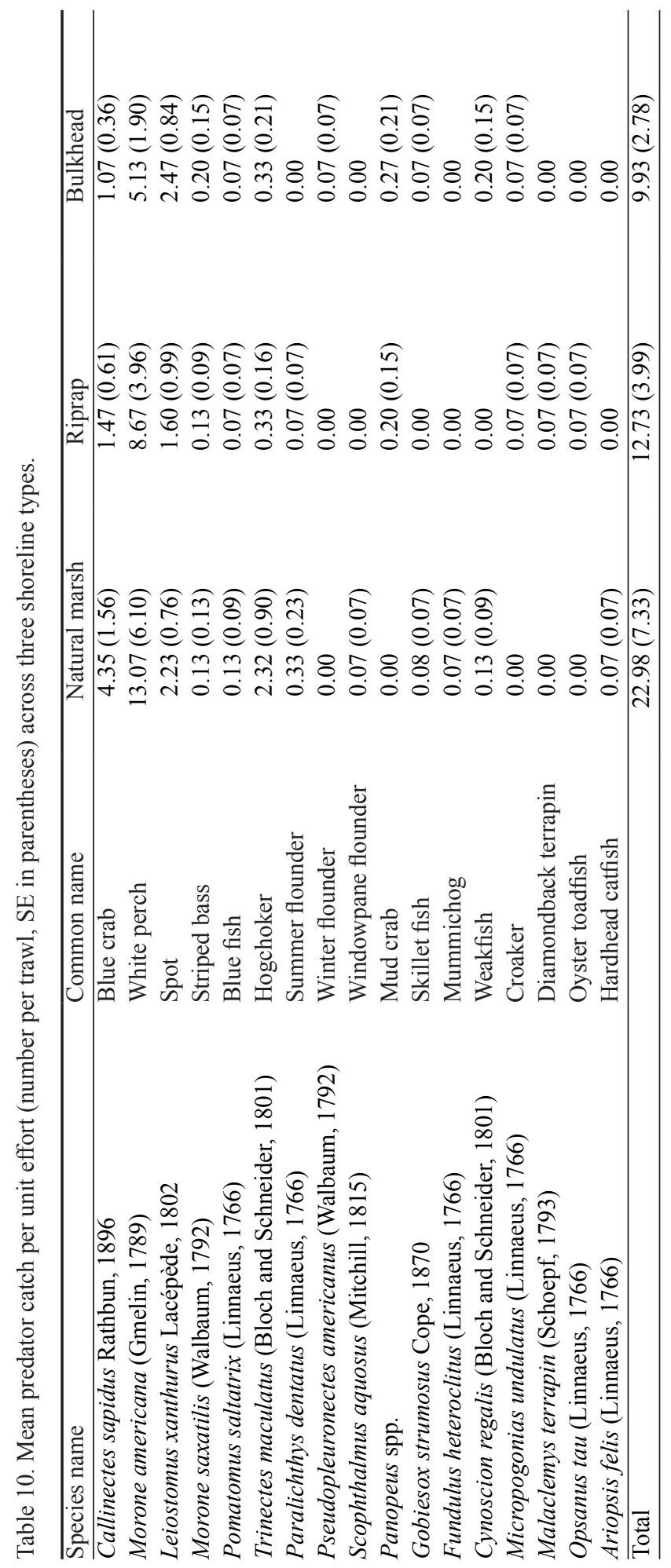



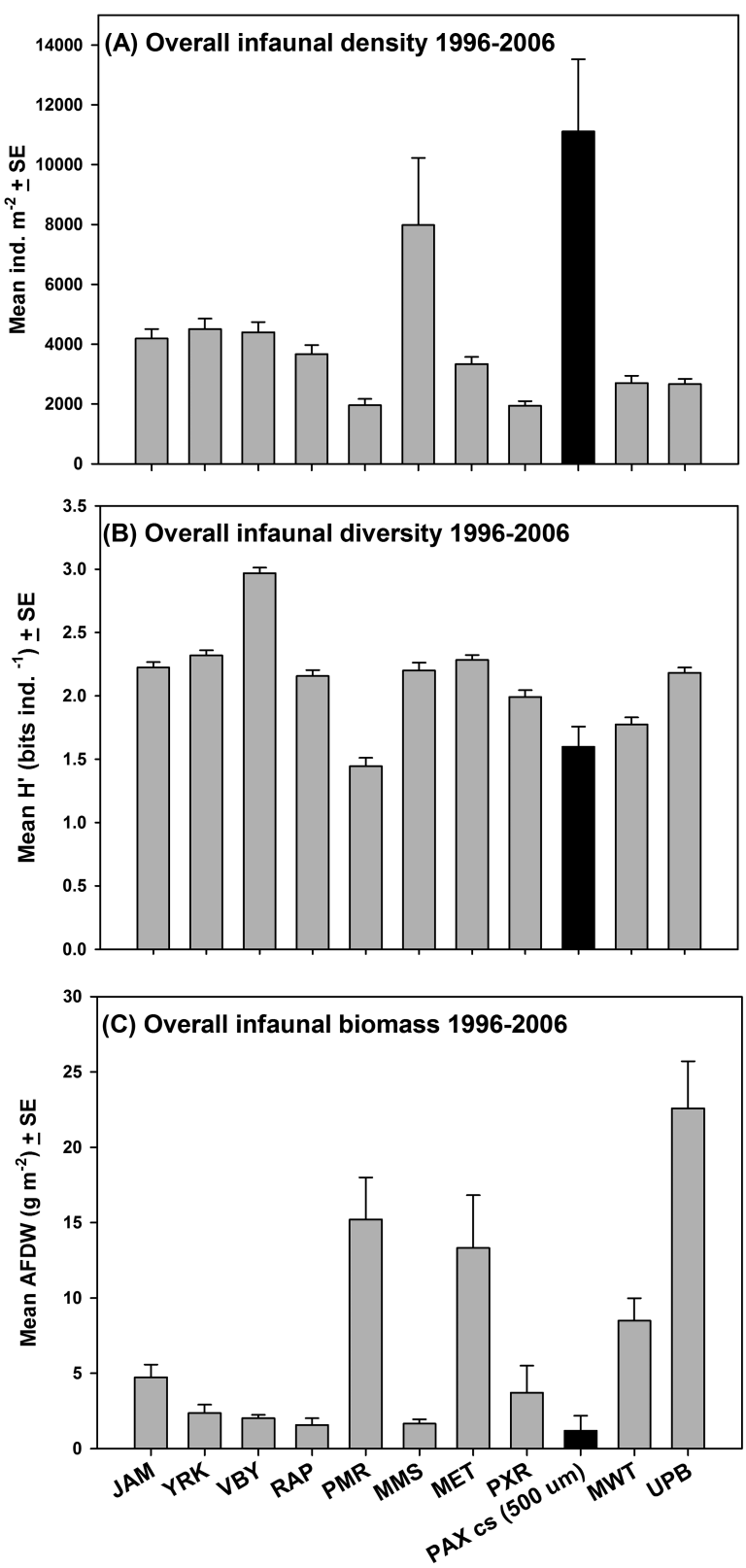

\section{Bay Stratum}

Figure 6. (A) Mean density ( \pm SE), (B) Shannon diversity, and (C) biomass of benthic infauna (all $500-\mu \mathrm{m}$ infauna) in primary Chesapeake Bay strata, as defined by the Chesapeake Bay Program (CBP; gray bars). From left to right along the $\mathrm{x}$-axis, tributaries from the lower to the upper Bay, defined as follows: JAM = James River; YRK = York River; VBY = Virginia Mainstem Bay; RAP $=$ Rappahannock River; PMR = Potomac River; MMS = Maryland Mainstem Bay; MET = Maryland Eastern Tributaries; PXR = Patuxent River; MWT = Maryland Western Tributaries; $\mathrm{UPB}=$ Upper Bay. Black bars represent $500-\mu \mathrm{m}$ data from the Patuxent River (PAX) current (2009) study (cs = current study, 500- $\mu \mathrm{m}$ infauna). Gray bars represent long-term means from 1996 to 2006 CBP data. 
suspended particles, which can clog filter-feeders' apparatuses and otherwise cause stress (Steele-Petrovic 1975, Fauchald and Jumars 1979). In addition, there may have been greater colonization at hardened sites via passive bedload transport of these small (G. gemma) individuals (Commito et al. 1995). At marsh habitats in our study, large deposit feeders, such as the pollution-sensitive bivalve L. balthica (Weisberg et al. 1997), were nearly 1.25 times denser than at bulkhead, whereas in the York River, marshes supported double the number of L. balthica as bulkhead (Seitz et al. 2006). The pattern in feeding mode is similar to previous studies where deposit-feeding bivalves had the highest densities adjacent to marsh compared to riprap or bulkhead habitats, whereas suspension-feeding bivalves tended to have highest densities at bulkhead shorelines (Seitz et al. 2006). The distribution of G. gemma emerged as a contributor to differences in 3-mm infauna among river zones (e.g., Fig. 3B), and environmental factors differed by shoreline and river zone. This suggests that there are some overriding broad-scale factors determining benthic infaunal responses. Greater G. gemma densities at downriver sites (Fig. 3B) suggest that conditions in the lower subestuary may be preferable for this highly opportunistic species (Commito et al. 1995).

We additionally expected that infaunal density and biomass would differ by environmental factors along with shoreline type. In $\mathrm{AIC}_{\mathrm{c}}$ comparisons, models with several factors, including shoreline type, wave energy, and chl- $a$, received strong support and many had reliable parameter estimates, indicating their influence on infaunal community structure. The moderate support for multiple $\mathrm{AIC}_{\mathrm{c}}$ models rather than a single dominant model in most cases suggests that a complex set of factors interact to influence benthic infauna, and that subtle differences by shoreline type can be detected in this system. Though the overall biomass and diversity in the present study were lower than those in previous studies with a similar experimental design (though 1-mm sieve size; Seitz et al. 2006, Lawless and Seitz 2014), the influence of sediment type and predators on biomass and diversity were apparent in this and previous studies (Seitz et al. 2006, Lawless and Seitz 2014). Our methodological approach was purposefully similar in many ways to other studies, both in Chesapeake Bay and elsewhere. However, our sample size of 15 per treatment shows an effort to detect changes within a depauperate system, compared with sample sizes per treatment of 4 in Puget Sound (Sobocinski et al. 2010), 6 in Wisconsin lakes (Jennings et al. 1999), and up to 8 in lower Chesapeake Bay (Seitz et al. 2006, Lawless and Seitz 2014). Moreover, the addition of non-parametric tests (e.g., nMDS) revealed slight differences by river zone, providing evidence that broad-scale effects might be as important as localized shoreline alterations in the Patuxent River.

Our expectation that benthic communities in the Patuxent River would exhibit a different overall response to shoreline hardening than more-pristine tributaries in lower Chesapeake Bay appeared to be supported, and further work on the relative influence of broad-scale factors (such as upland watershed development) in this system may clarify mechanisms behind these patterns (R Seitz, VIMS, unpubl data). In a large-scale study in multiple tributaries throughout Chesapeake Bay, as the proportion of near-shore developed land in a watershed increased, the infaunal biomass declined, reducing the infaunal prey available to higher trophic levels (R Seitz, VIMS, unpubl data). The inflow of nutrients, toxicants, and sediments can increase with increased runoff over hardened surfaces where upland development is high (Jordan et al. 1997, Howarth et al. 2011, Gregg et al. 2015), and benthic species, especially 
long-lived, pollution-sensitive species, are stressed and respond negatively (Weisberg et al. 1997). The importance of broad-scale factors on distribution and densities of select benthic species has been demonstrated (King et al. 2005), and broad-scale factors are suggested to be more important than shoreline development in determining patterns of benthic infauna in other systems, such as the Pascagoula River estuary in Mississippi (Partyka and Peterson 2008).

Many of the variables that emerged as important predictors in the $\mathrm{AIC}_{\mathrm{c}}$ analysis exhibited trends that varied by shoreline type (e.g., sediment type, wave energy), which may have limited our ability to discern between direct and indirect effects on infauna. Subtle differences in infauna due to wave energy, sediment type, etc., may be secondary impacts of shoreline type. For example, an increase in wave energy may be the result of wave reflection directly off of hard structures. However, the propensity of coastal landowners to harden their shoreline in response to already elevated wind/wave energy makes the effects of these two variables on infauna difficult to tease apart. Moreover, although we excluded "double shorelines" (e.g., marsh with riprap present, marsh with bulkhead present) in our study, future examination of these types of shorelines could help to determine whether any observed impacts on the benthos are due to the loss of marsh habitat or the addition of artificial structure that could affect secondary factors such as wave energy. Wave energy (RWE) effects may help to explain the influence of other measured variables, particularly sediment grain size, on infauna. The relatively higher wind/wave energy at hardened sites (and coarser sediments) may have delivered more water-column food particles (Emerson 1989, Leonard et al. 1998, Schaffner et al. 2001), thus, supporting greater numbers of suspension feeders such as G. gemma (Table 3). Alternatively, dense populations of G. gemma at hardened sites may have inhibited recruitment of other suspension feeders by outcompeting others for food and/or space (e.g., Kennedy and Mihursky 1971). Fine sediments in marsh habitats (where wave energy was lowest) could allow a more even distribution of species and feeding modes (Table 3, Fig. 5), rather than the dominance of suspension-feeders (e.g., G. gemma) seen at hardened shorelines. Additionally, the organic matter exported from salt marshes plays a role in the food web of these habitats (Teal 1962, Currin et al. 1995), particularly for deposit-feeding species (Grall and Chauvaud 2002). Thus, differences in food availability (i.e., allochthonous organic carbon) may contribute to the wider range of species and feeding modes of small infauna at marshes.

High infaunal biomass in conjunction with natural marsh as opposed to bulkhead (Fig. 2C, F) is consistent with observations of bivalve biomass in the York River, in lower Chesapeake Bay (Seitz et al. 2006). Organic enrichment in sediments can cause stress in the benthos, as oxygen is depleted and toxins accumulate (Pearson and Rosenberg 1978, Hyland et al. 2005). However, there may be greater infaunal biomass in association with moderate levels of sediment organic carbon (Herman et al. 1999, Seitz and Lipcius 2001, Kemp et al. 2005), an important infaunal food source (Sanders 1958, Lopez and Levinton 1987). There is little evidence to directly link changes in sediment TOC with changes in infaunal communities adjacent to natural vs hardened shorelines (Partyka and Peterson 2008, Lawless and Seitz 2014). However, the organic-rich fine sediments of marshes in the Patuxent River may support greater biomass and a more productive, though less dense, benthic community than developed shorelines (Fig. 2C, F). Although riprap supported a biomass comparable with marsh sites for $500-\mu \mathrm{m}$ infauna, this was likely due to both the presence 
of relatively large (though fewer) individual M. arenaria, and the high densities (particularly of G. gemma) at that shoreline type.

There were greater abundances of benthic fishes and crabs associated with natural vs hardened shorelines in our study, a pattern that also occurs in lower Chesapeake Bay (Seitz et al. 2006, Bilkovic and Roggero 2008), as well as other estuarine (Peterson et al. 2000, Morley et al. 2012) and freshwater (Jennings et al. 1999, Goforth and Carman 2009) systems. This relationship between mobile fauna and shoreline type has been attributed to the structural heterogeneity associated with natural coasts (Bilkovic and Roggero 2008; D Bilkovic and M Mitchell, VIMS, unpubl data). Estuarine nekton can respond to differences in food availability, and positive relationships between predators and their infaunal and/or epifaunal prey can occur (Seitz et al. 2006, Partyka and Peterson 2008, Morley et al. 2012), as seen in our study, suggesting the influence of bottom-up (e.g., resource) control in these systems (Seitz et al. 2003).

Despite the highly developed watershed, benthos in the Patuxent River exhibited subtle differences by shoreline type. Benthic infaunal responses to shoreline alteration showed similar trends as previous work in lower Chesapeake Bay, but were lower in magnitude than other bay tributaries overall (e.g., Fig. 6). Given that the benthos in the Patuxent River is depauperate compared to other bay tributaries (D Dauer, Old Dominion University, pers comm; Ruggiero and Merchant 1979, Costanza et al. 2002), there is little scope for change among habitats compared to that seen in other systems (e.g., Seitz et al. 2006). Depauperate benthic communities in marine and estuarine systems often are associated with anthropogenic influences such as nutrient and/or pollutant loading (Dauer et al. 2000, Grall and Chauvaud 2002, Rabalais 2002, Hyland et al. 2005, Kutcher 2009) and habitat degradation (reviewed in Kennish 2002, Lotze et al. 2006). Shoreline hardening reduces ecosystem services and functions afforded to benthic communities by marshes (Weis et al. 1998, Peterson et al. 2000, Long et al. 2011, Gittman et al. 2016), and shoreline development effects can still be seen despite a high level of broad-scale disturbance in the system. A threshold effect has been demonstrated for broad-scale watershed land use and impervious surface as relates to fishes and coastal nekton in Chesapeake Bay (Bilkovic and Roggero 2008) and may prove useful if expanded to include subtidal benthic infauna.

An examination of watershed land use and associated activities along the length of the Patuxent River may provide more insight into parameters outside of those measured in the present study that may contribute to change in nearshore conditions. Development and associated human-induced loadings (e.g., nitrogen, phosphorus) at the landscape level may play a considerable role in the overall quality of the estuary through the varied effects and consequences of eutrophication (e.g., Nixon 1995). While upland development thresholds have been examined for nearshore nekton (Bilkovic and Roggero 2008), future work should aim to identify development thresholds as they pertain to subtidal benthic infauna to link upland land use to an estuary's ability to buffer negative impacts based on the remaining amount of pristine, beneficial habitat. Identifying critical development thresholds for multiple aspects of estuarine food webs (i.e., beyond mobile fishes and other megafauna) will allow for more refined management approaches, and may help to direct limited funds for restoration activities toward high-need areas that have the potential to rebound from disturbance. 
Both high total marsh percentage (Seitz and Lawless 2008) and marsh spatial connectivity (Partyka and Peterson 2008) support more robust benthic communities, highlighting the necessity for a system-wide approach to estuarine shoreline restoration. Even in heavily impacted mesohaline systems in coastal Mississippi, natural shorelines provide a higher level of habitat suitability for nearshore nekton communities; however, there were only marginal differences in infauna by shore type and the "presence of marsh habitat is not enough to ensure a high level of ecosystem health" (Partyka and Peterson 2008). Our results show that mesohaline Chesapeake Bay may similarly experience only subtle impacts by shoreline development alone, and this may have important implications for future restoration efforts in the Chesapeake Bay and other estuaries. Rather than only replacing or connecting lost natural marsh, methods to restore overall benthic integrity in the Patuxent River and other degraded estuaries will rely on also improving broader watershed-level activities to influence local benthic communities.

\section{ACKNOWLEDGMENTS}

Funding was provided by the National Oceanic and Atmospheric Administration CSCOR program (Grant \# NA09NOS4780221) and the National Science Foundation Research Experiences for Undergraduates program. We thank staff and students from the Virginia Institute of Marine Science Community Ecology and Marine Conservation Biology labs for field, lab, and statistical assistance. We also thank D Dauer for benthic data from the Chesapeake Bay Program, and D Bilkovic and R Lipcius for their review of and suggestions for this manuscript. This is contribution number 3601 from the Virginia Institute of Marine Science.

\section{Literature Cited}

Anderson DR. 2008. Model based inference in the life sciences. Springer Science +Business Media, LLC, New York, NY, USA.

Anderson DR, Burnham KP, White GC. 2001. Kullback-Leibler information in resolving natural resource conflicts when definitive data exist. Wildlife Soc B. 29(4):1260-1270. https:// pubs.er.usgs.gov/publication/70023510

Airoldi L, Bulleri F. 2011. Anthropogenic disturbance can determine the magnitude of opportunistic species responses on marine urban infrastructures. PLoS One. 6:e22985. http:// dx.doi.org/10.1371/journal.pone.0022985

Ahn IY, Choi JW. 1998. Macrobenthic communities impacted by anthropogenic activities in an intertidal sand flat on the west coast (Yellow Sea) of Korea. Mar Pollut Bull. 36:808-817. http://dx.doi.org/10.1016/S0025-326X(98)00061-7

Berman MR, Berquist H, Dewing S, Hershner CH, Rudnicky T, Barbosa A, Schatt DE, Weiss D, Woods H. 2003. St. Mary's County, Maryland shoreline situation report, Comprehensive Coastal Inventory Program, Virginia Institute of Marine Science, The College of William \& Mary, Gloucester Point, VA. Accessed 30 January, 2016. http://ccrm.vims.edu/gis_data_ maps/shoreline_inventories/maryland/stmary/stmary_disclaimer.html

Berman MR, Berquist H, Killeen S, Nunez K, Rudnicky T, Schatt DE, Weiss D, Reay K. 2006. Calvert County, Maryland shoreline situation report, Comprehensive Coastal Inventory Program, Virginia Institute of Marine Science, The College of William \& Mary, Gloucester Point, VA. Accessed 30 January, 2016. http://ccrm.vims.edu/gis_data_maps/shoreline_inventories/maryland/calvert/calvert_disclaimer.html

Bertness MD. 200\%. Atlantic shorelines: natural history and ecology. Princeton University Press, Princeton, New Jersey. 
Bianchi TS, Rice DL. 1988. Feeding ecology of Leitoscoloplos fragilis II. effects of worm density on benthic diatom production. Mar Biol. 99:123-131. http://dx.doi.org/10.1007/ BF00644986

Bilkovic DM, Mitchell MM. 2013. Ecological tradeoffs of stabilized salt marshes as a shoreline protection strategy: effects of artificial structures on macrobenthic assemblages. Ecol Eng. 61:469-481. http://dx.doi.org/10.1016/j.ecoleng.2013.10.011

Bilkovic DM, Roggero M. 2008. Effects of coastal development on nearshore estuarine nekton communities. Mar Ecol Prog Ser. 358:27-39. http://dx.doi.org/10.3354/meps07279

Bilkovic DM, Roggero M, Hershner CH, Havens KH. 2006. Influence of land use on macrobenthic communities in nearshore estuarine habitats. Estuaries Coasts. 29:1185-1195. http:// dx.doi.org/10.1007/BF02781819

Boesch DF. 1973. Classification and community structure of macrobenthos in the Hampton Roads area, Virginia. Mar Biol. 21:226-244. http://dx.doi.org/10.1007/BF00355253

Boynton WR, Hagy JD, Cornwell JC, Kemp WM, Greene SM, Owens MS, Baker JE, Larsen RK. 2008. Nutrient budgets and management actions in the Patuxent River estuary, Maryland. Estuaries Coasts. 31:623-651. http://dx.doi.org/10.1007/s12237-008-9052-9

Bradley CD. 2011. The impact of shoreline development on shallow-water benthic communities in the Patuxent River, MD. Master's thesis. The College of William \& Mary. Gloucester Point, Virginia. $94 \mathrm{p}$.

Browne MA, Chapman MG. 2011. Ecologically informed engineering reduces loss of intertidal biodiversity on artificial shorelines. Environ Sci Technol. 45(19):8204-8207. http://dx.doi. org/10.1021/es201924b

Burke RP. 2010. Alternative substrates as a native oyster (Crassostrea virginica) reef restoration strategy in Chesapeake Bay. PhD dissertation, The College of William \& Mary, Gloucester Point, VA.

Burnham KP, Anderson DR. 2002. Model selection and multimodel inference: a practical information-theoretic approach, 2nd ed. Springer Science + Business Media, LLC, New York, NY.

Chapman MG, Underwood AJ. 2011. Evaluation of ecological engineering of "armoured" shorelines to improve their value as habitat. J Exp Mar Biol Ecol. 400:302-313. http:// dx.doi.org/10.1016/j.jembe.2011.02.025

Clarke KR, Gorley RN. 2006. PRIMER v6: user manual/tutorial. PRIMER-E, Plymouth.

Clarke KR, Warwick RM. 2001. Change in marine communities: an approach to statistical analysis and interpretation, 2nd edition. PRIMER-E, Plymouth.

Commito J, Currier CA, Kane LR, Reinsel KA, Ulm IM. 1995. Dispersal dynamics of the bivalve Gemma gemma in a patchy environment. Ecol Monogr. 65:1-20. http://dx.doi. org $/ 10.2307 / 2937157$

Costanza R, Voinov A, Boumans R, Maxwell T, Villa F, Wainger L, Voinov H. 2002. Integrated ecological economic modeling of the Patuxent River watershed, Maryland. Ecol Monogr. 72:203-231. http://dx.doi.org/10.1890/0012-9615(2002)072[0203:IEEMOT]2.0.CO;2

Cunha MR, Moreira MH, Sorbe JC. 2000. The amphipod Corophium multisetosum (Corophiidae) in Ria de Aveiro (NW Portugal). II. Abundance, biomass, and production. Mar Biol. 137:651-660. http://dx.doi.org/10.1007/s002270000385

Currin CA, Newell SY, Paeri HW. 1995. The role of standing dead Spartina alterniflora and benthic microalgae in salt marsh food webs: considerations based on multiple stable isotope analysis. Mar Ecol Prog Ser. 121:99-116. http://dx.doi.org/10.3354/meps121099

Dail HM, Kazyak PF, Boward DM, Stranko SA. 1998. Patuxent River Basin: environmental assessment of stream conditions. Maryland Department of Natural Resources, Resource Assessment Service. Monitoring and non-tidal assessment division. Annapolis, MD.

Dauer DM. 1993. Biological criteria, environmental health and estuarine macrobenthic community structure. Mar Pollut Bull. 26:249-257. http://dx.doi. org/10.1016/0025-326X(93)90063-P 
Dauer DM, Ranasinghe JA, Weisberg SB. 2000. Relationships between benthic community condition, water quality, sediment quality, nutrient loads, and land use patterns in Chesapeake Bay. Estuaries. 23:80-96. http://dx.doi.org/10.2307/1353227

Diaz RJ, Schaffner LC. 1990. The functional role of estuarine benthos. In: Haire M, Krome EC, editors. Perspectives on the Chesapeake Bay, 1990. Advances in estuarine sciences, Report no. CBP/TRS41/90. Chesapeake Research Consortium, Gloucester Point, VA, p 25-56.

Dugan JE, Airoldi L, Chapman MG, Walker SJ, Schlacher T. 2011. 8.02 Estuarine and coastal structures: environmental effects, a focus on shore and nearshore structures. In: Wolanski E, McLusky D, editors. Treatise on estuarine and coastal science. Academic Press, Waltham. $17-41$.

Eggleston DB, Lipcius RN, Hines AH. 1992. Density-dependent predation by blue crabs upon infaunal clam species with contrasting distribution and abundance patterns. Mar Ecol Prog Ser. 85:55-68. http://dx.doi.org/10.3354/meps085055

Emerson CW. 1989. Wind stress limitation of benthic secondary production in shallow, soft-sediment communities. Mar Ecol Prog Ser. 53:65-77. http://dx.doi.org/10.3354/ meps053065

Fauchald K, Jumars PA. 1979. The diet of worms: a study of polychaete feeding guilds. Oceanogr Mar Biol Annu Rev. 17:193-284.

Gedan KB, Silliman BR, Bertness MD. 2009. Centuries of human-driven change in salt marsh ecosystems. Annu Rev Mar Sci. 1:117-141. http://dx.doi.org/10.1146/annurev. marine.010908.163930

Gittman RK, Fodrie FJ, Popowich AM, Keller DA, Bruno JF, Currin CA, Peterson CH, Piehler MF. 2015. Engineering away our natural defenses: an analysis of shoreline hardening in the US. Front Ecol Environ. 13:301-307. http://dx.doi.org/10.1890/150065

Gittman RK, Peterson CH, Currin CA, Fodrie F), Piehler MF, Bruno JF. 2016. Living shorelines can enhance the nursery role of threatened estuarine habitats. Ecol Appl. 26:249-263. http://dx.doi.org/10.1890/14-0716

Goforth RR, Carman SM. 2009. Multiscale relationships between Great Lakes nearshore fish communities and anthropogenic shoreline factors. J Gt Lakes Res. 35:215-223. http:// dx.doi.org/10.1016/j.jglr.2009.02.001

Grall J, Chauvaud L. 2002. Marine eutrophication and benthos: the need for new approaches and concepts. GlobChange Biol. 8:813-830.http://dx.doi.org/10.1046/j.1365-2486.2002.00519.x

Gregg T, PrahI FG, Simoneit BRT. 2015. Suspended particulate matter transport of polycyclic aromatic hydrocarbons in the lower Columbia River and its estuary. Limnol Oceanogr. 60(6):1935-1949. http://dx.doi.org/10.1002/lno.10144

Hentschel BT. 1998. Intraspecific variations in $\delta^{15} \mathrm{C}$ indicate ontogenetic diet changes in deposit-feeding polychaetes. Ecology. 79:1357-1370. http://dx.doi. org/10.1890/0012-9658(1998)079[1357:IVICIO]2.0.CO;2

Herman PMJ, Middelburg JJ, Van De Koppel J, Heip CHR. 1999. Ecology of estuarine macrobenthos. Adv Ecol Res. 29:195-240. http://dx.doi.org/10.1016/S0065-2504(08)60194-4

Hines AH, Haddon AM, Wiechert LA. 1990. Guild structure and foraging impact of blue crabs and epibenthic fish in a subestuary of Chesapeake Bay. Mar Ecol Prog Ser. 67:105-126. http://dx.doi.org/10.3354/meps067105

Holland AF, Shaughnessy AT, Hiegel MH. 1987. Long-term variation in mesohaline Chesapeake Bay macrobenthos: spatial and temporal patterns. Estuaries Coasts. 10:227-245. http:// dx.doi.org/10.2307/1351851

Howarth R, Chan F, Conley DJ, Garnier J, Doney SC, Marino R, Billen G. 2011. Coupled biogeochemical cycles: eutrophication and hypoxia in temperate estuaries and coastal marine ecosystems. Front Ecol Environ. 9:18-26. http://dx.doi.org/10.1890/100008

Hyland J, Balthis L, Karakassis I, Magni P, Petrov A, Shine J, Vestergaard O, Warwick R. 2005. Organic carbon content of sediments as an indicator of stress in the marine benthos. Mar Ecol Prog Ser. 295:91-103. http://dx.doi.org/10.3354/meps295091 
Jackson JBC. 1968. Bivalves: spatial and size-frequency distribution of two intertidal species. Science. 161:479-480. http://dx.doi.org/10.1126/science.161.3840.479

Jennings MJ, Bozek MA, Hatzenbeler GR, Emmons EE, Staggs MD. 1999. Cumulative effects of incremental shoreline habitat modification on fish assemblages in north temperate lakes. N Am J Fish Manage. 19:18-27. http://dx.doi.org/10.1577/1548-8675(1999)019<0018:CEO ISH>2.0.CO;2

Jordan TE, Correll DL, Weller DE. 1997. Effects of agriculture on discharges of nutrients from coastal plain watershed of Chesapeake Bay. J Environ Qual. 26:836-848. http://dx.doi. org/10.2134/jeq1997.00472425002600030034र

Karlson K, Bonsdorff E, Rosenberg R. 2007. The impact of benthic macrofauna for nutrient fluxes from Baltic Sea sediments. Ambio. 36:161-167. http://dx.doi. org/10.1579/0044-7447(2007)36[161:TIOBMF]2.0.CO;2

Kemp WM, Boynton WR, Adolf JE, Boesch DF, Bolcourt WC, Brush G, Cornwell JC, Fisher TR, Gilbert PM, Hagy JD, et al. 2005. Eutrophication of Chesapeake Bay: historical trends and ecological interactions. Mar Ecol Prog Ser. 303:1-29. http://dx.doi.org/10.3354/ meps303001

Kennedy VS, Mihursky JA. 1971. Upper temperature tolerances of some estuarine bivalves. Chesap Sci. 12:193-204. http://dx.doi.org/10.2307/1350906

Kennish MJ. 2002. Environmental threats and environmental future of estuaries. Environ Conserv. 29:78-107. http://dx.doi.org/10.1017/S0376892902000061

King RS, Hines AH, Craige FD, Grap S. 2005. Regional, watershed, and local correlates of blue crab and bivalve abundances in subestuaries of Chesapeake Bay, USA. J Exp Mar Biol Ecol. 319:101-116. http://dx.doi.org/10.1016/j.jembe.2004.05.022

Kutcher TE. 2009. Human impacts on Narragansett Bay. In: Raposa KB, Schwartz ML, editors. An ecological profile of the Narragansett Bay National Estuarine Research Reserve. Chapter 12. Narragansett Bay National Estuarine Research Reserve. Prudence, Rhode Island. Accessed 6 February, 2106. Available from: http://www.nbnerr.org/Content/ SiteProfile08/14_Chapter\%2012_Human\%20Impacts.pdf

Lawless AS, Seltz RD. 2014. Effects of shoreline stabilization and environmental variables on benthic infaunal communities in the Lynnhaven River system of Chesapeake Bay. J Exp Mar Biol Ecol. 457:41-50. http://dx.doi.org/10.1016/j.jembe.2014.03.010

Leonard GH, Levine JM, Schmidt PR, Bertness MD. 1998. Flow-driven variation in intertidal community structure in a Maine estuary. Ecology. 79:1395-1411. http://dx.doi. org/10.1890/0012-9658(1998)079[1395:FDVIIC]2.0.CO;2

Lerberg SB, Holland AF, Sanger DM. 2000. Responses of tidal creek macrobenthic communities to the effects of watershed development. Estuaries. 23:838-853. http://dx.doi. org $/ 10.2307 / 1353001$

Lotze HK, Lenihan HS, Bourque BJ, Bradbury RH, Cooke RG, Kay MC, Kidwell SM, Kirby MX, Peterson CH, Jackson JBC. 2006. Depletion, degradation, and recovery potential of estuaries and coastal seas. Science. 312:1806-1809. http://dx.doi.org/10.1126/science.1128035

Long WC, Grow JN, Majoris JE, Hines AH. 2011. Effects of anthropogenic shoreline hardening and invasion by Phragmites australis on habitat quality for juvenile blue crabs (Callinectes sapidus). J Exp Mar Biol Ecol. 409:215-222. http://dx.doi.org/10.1016/j.jembe.2011.08.024

Lopez GR, Levinton JS. 1987. Ecology of deposit-feeding animals in marine sediments. Q Rev Biol. 62:235-260. http://dx.doi.org/10.1086/415511

Lorenzen C). 1967. Determination of chlorophyll and pheo-pigments: spectrophotometric equations. Limnol Oceanogr. 12:343-346. http://dx.doi.org/10.4319/lo.1967.12.2.0343

Malhotra A, Fonseca M. 2007. WEMo (Wave Exposure Model): formulation, procedures and validation. NOAA technical memorandum NOS NCCOS \#65. Beaufort, NC.

Miles JR, Russell PE, Huntley DA. 1996. Sediment transport and wave reflection near a seawall. Coast Eng Proc 1. 
Morley SA, Toft JD, Hanson KM. 2012. Ecological effects of shoreline armoring on intertidal habitats of a Puget Sound urban estuary. Estuaries Coasts. 35:774-784. http://dx.doi. org/10.1007/s12237-012-9481-3

Nixon SW. 1995. Coastal marine eutrophication: a definition, social causes, and future concerns. Ophelia. 41:199-219. http://dx.doi.org/10.1080/00785236.1995.10422044

Orth RJ, van Montfrans J. 1987. Utiliation of a seagrass meadow and tidal marsh creek by blue crabs Callinectes sapidus I. Seasonal and annual variation in abundance with emphasis on post-settlement juveniles. Mar Ecol Prog Ser. 41:283-294. http://dx.doi.org/10.3354/ meps041283

Partyka ML, Peterson MS. 2008. Habitat quality and salt-marsh species assemblages along an anthropogenic estuarine landscape. J Coast Res. 24:1570-1581. http://dx.doi. org/10.2112/07-0937.1

Pearson TH, Rosenberg R. 1978. Macrobenthic succession in relation to organic enrichment and pollution of the marine environment. Oceanogr Mar Biol Annu Rev. 16:229-311.

Peterson MS, Lowe MR. 2009. Implications of cumulative impacts to estuarine and marine habitat quality for fish and invertebrate resources. Rev Fish Res. 17:505-523.

Peterson MS, Comyns BH, Hendon JR, Bond PJ, Duff GA. 2000. Habitat use by early life-history stages of fishes and crustaceans along a changing estuarine landscape: differences between natural and altered shoreline sites. Wetlands Ecol Manage. 8:209-219. http://dx.doi. org/10.1023/A:1008452805584

Pinckney J, Zingmark RG. 1993. Biomass and production of benthic microalgal communities in estuarine habitats. Estuaries. 16:887-897. http://dx.doi.org/10.2307/1352447

Plumb RH. 1981. Procedures for handling and chemical analysis of sediment and water samples. Technical report EPA/CE-81-1. Prepared by Great Lakes laboratory, State University College at Buffalo, Buffalo, NY for the US Environmental Protection Agency/Corps of Engineers technical committee on criteria for dredged and fill material: Environmental Laboratory, US Army waterways experiment station. Vicksburg, MS.

Rader DN. 1984. Salt-marsh benthic invertebrates: small-scale patterns of distribution and abundance. Estuaries. 7:413-420. http://dx.doi.org/10.2307/1351622

Rabalais N. 2002. Nitrogen in aquatic systems. Ambio. 31:102-112. http://dx.doi. org/10.1579/0044-7447-31.2.102

Rosenberger EE, Hampton SE, Fradkin SC, Kennedy BP. 2008. Effects of shoreline development on the nearshore environment in large deep oligotrophic lakes. Freshw Biol. 53:1673-1691. http://dx.doi.org/10.1111/j.1365-2427.2008.01990.x

Ruggiero MA, Merchant HC. 1979. Water quality, substrate, and distribution of macroinvertebrates in the Patuxent River, Maryland. Hydrobiologia. 64:183-189. http://dx.doi. org/10.1007/BF00023195

Ruppert E, Fox R. 1988. Seashore animals of the southeast. University of South Carolina Press, Columbia, SC.

Sanders HL. 1958. Benthic studies in Buzzards Bay. I. animal-sediment relationships. Limnol Oceanogr. 3(3):245-258. http://dx.doi.org/10.4319/1o.1958.3.3.0245

Schaffner LC, Dellapenna TM, Hinchey EK, Friedrichs CT, Neubauer MT, Smith ME, Kuehl SA. 2001. Physical energy regimes, seabed dynamics, and organism-sediment interactions along an estuarine gradient. In: Aller JY, Woodin SA, Aller RC, editors. Organism-sediment interactions. University of South Carolina Press, Columbia, SC, p. 161-182.

Seitz RD, Lawless AS. 2008. Landscape-level impacts of shoreline development upon Chesapeake Bay benthos and their predators. In: Erdle SY, Davis JL, Sellner KG, editors. Management policy, science and engineering of nonstructural erosion control in the Chesapeake Bay. Proc 2006 living shoreline summit. CRC Publ. 08-164, CRC Press, Gloucester Point, VA. pp. 63-70.

Seitz RD, Lipcius RN. 2001. Variation in top-down and bottom-up control of marine bivalves at differing spatial scales. ICES J Mar Sci. 58:689-699. http://dx.doi.org/10.1006/ jmsc.2001.1054 
Seitz RD, Dauer DM, Llansó RJ, Long WC. 2009. Broad-scale effects of hypoxia on benthic community structure in Chesapeake Bay, USA. J Exp Mar Biol Ecol. 381:S4-S12. http:// dx.doi.org/10.1016/j.jembe.2009.07.004

Seitz RD, Lipcius RN, Olmstead NH, Seebo MS, Lambert DM. 2006. Influence of shallowwater habitats and shoreline development on abundance, biomass, and diversity of benthic prey and predators in Chesapeake Bay. Mar Ecol Prog Ser. 326:11-27. http://dx.doi. org $/ 10.3354 /$ meps 326011

Seitz RD, Lipcius RN, Stockhausen WT, Delano KA, Seebo MS, Gerdes PD. 2003. Potential bottom-up control of blue crab distribution at various spatial scales. Bull Mar Sci. 72:471-490.

Snelgrove PVR, Austin MC, Boucher G, Heip C, Hutchings PA, King GM, Koike 1, Lambshead PJD, Smith CR. 2000. Linking biodiversity above and below the marine sediment-water interface. Bioscience. 50:1076-1088. http://dx.doi.org/10.1641/0006-3568(2000)050[1076:LB AABT] 2.0.CO;2

Snelgrove PVR, Butman CA. 1994. Animal-sediment relationships revisited: cause versus effect. Oceanogr Mar Biol Annu Rev. 32:111-117.

Sobocinski KL, Cordell JR, Simenstad CA. 2010. Effects of shoreline modifications on supratidal macroinvertebrate fauna on Puget Sound, Washington beaches. Estuaries Coasts. 33:699-711. http://dx.doi.org/10.1007/s12237-009-9262-9

Steele-Petrovic HM. 19/5. An explanation for the tolerance of brachiopods and relative intolerance of filter-feeding bivalves for soft muddy bottoms. J Paleontol. 49:552-556.

Teal JM. 1962. Energy flow in a saltmarsh ecosystem of Georgia. Ecology. 43:614-624. http:// dx.doi.org/10.2307/1933451

Thrush SF. 1999. Complex role of predators in structuring soft-sediment macrobenthic communities: implications of changes in spatial scale for experimental studies. Aust J Ecol. 24:344-354. http://dx.doi.org/10.1046/j.1442-9993.1999.00981.x

US Coastal Engineering Research Center (USCOE). 1977. Shore protection manual, vol. 1. US Army Coastal Engineering Research Center, Ft. Belvoir, VA.

Valiela I. 1995. Marine ecological processes, $2^{\text {nd }}$ ed. Springer Science+Business Media, LLC., New York, NY.

Virnstein RW. 1977. The importance of predation by crabs and fishes on benthic infauna in Chesapeake Bay. Ecology. 58:1199-1217. http://dx.doi.org/10.2307/1935076

Weis JS, Weis P, Proctor T. 1998. The extent of benthic impacts of CCA-treated wood structures in Atlantic coast estuaries. Arch Environ Contam Toxicol. 34:313-322. http://dx.doi. org/10.1007/s002449900324

Weisberg SB, Ranasinghe JA, Dauer DM, Schaffner LC, Diaz RJ, Frithsen JB. 1997. An estuarine benthic index of biotic integrity (B-IBI) for Chesapeake Bay. Estuaries. 20:149-158. http:// dx.doi.org/10.2307/1352728

Wilcox JR, Jeffries HP. 1974. Feeding habits of the sand shrimp Crangon Septemspinosa. Biol Bull. 146:424-434. http://dx.doi.org/10.2307/1540416

Ysebaert T, Fettweis M, Meire P, Sas M. 2005. Benthic variability in intertidal soft-sediments in the mesohaline part of the Schelde estuary. Hydrobiologia. 540:197-216. http://dx.doi. org/10.1007/s10750-004-7144-5

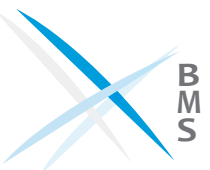

